ח

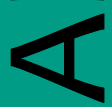

n

Ш

Z

O

$\underline{-}$

$F$

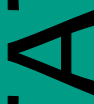

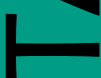

ه

Ш

n

n

$\overline{0}$
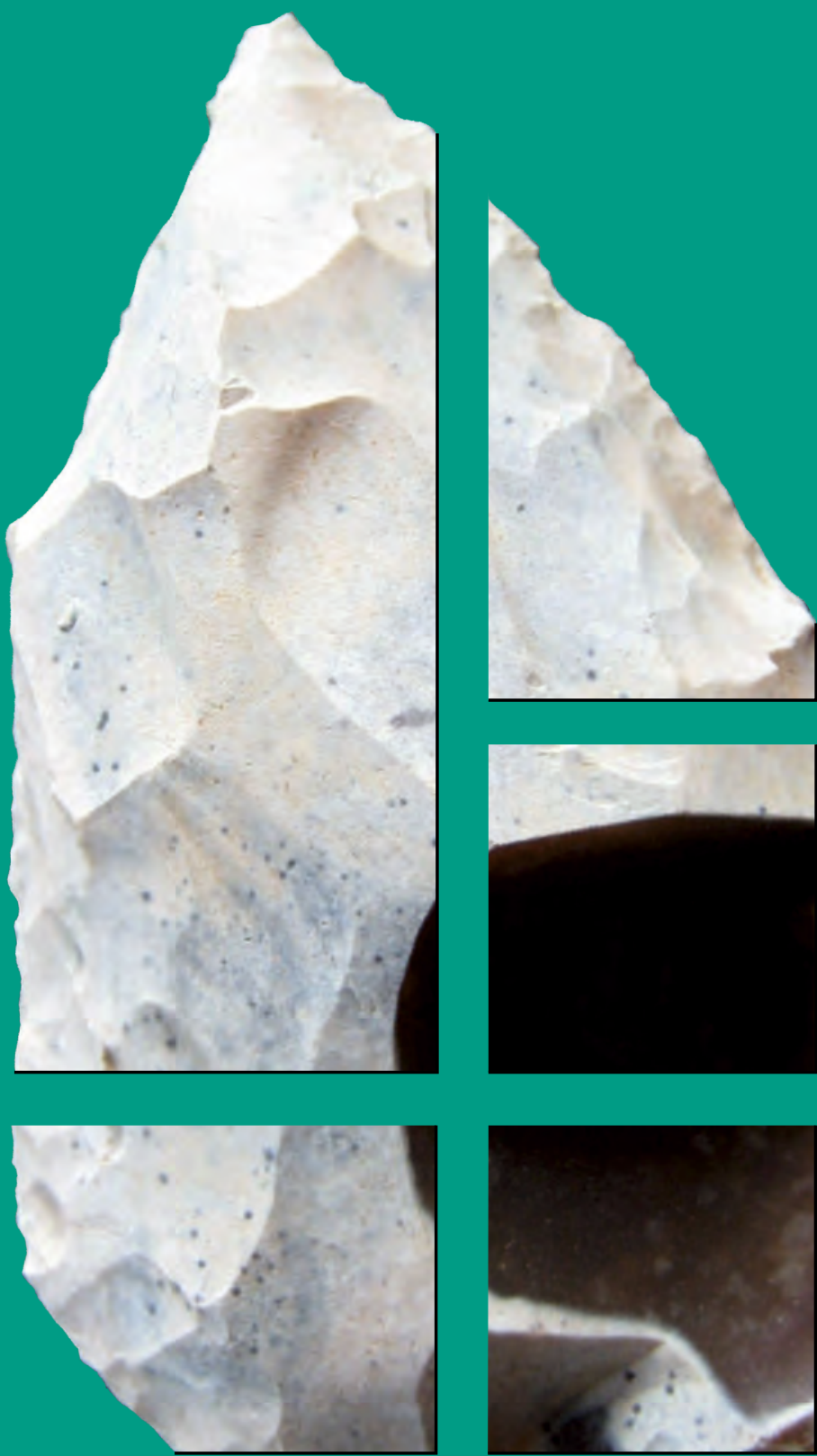

Ser. 3. No.9.| 2021 


\section{Dissertationes Archaeologicae ex Instituto Archaeologico}

Universitatis de Rolando Eötvös nominatae

Ser. 3. No. 9.

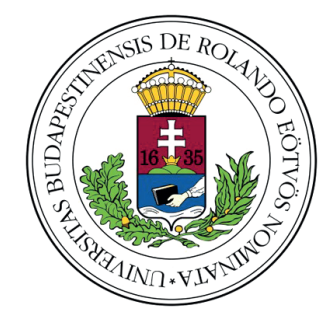

Budapest 2021 


\section{Dissertationes Archaeologicae ex Instituto Archaeologico Universitatis de Rolando Eötvös nominatae}

Ser. 3. No. 9.

Editor-in-chief

Dávid BARTus

Editorial board

László Bartosiewicz (Stockholm University, Stockholm)

Ondřej Chvojкa (University of South Bohemia, České Budějovice)

Zoltán Czajlik (Eötvös Loránd University, Budapest)

Mario Gavranović (Austrian Arhaeological Institute AAS, Vienna)

Hajnalka Herold (University of Exeter, Exeter)

Klára Kuzmová (University of Trnava, Trnava)

Tina Milavec (University of Ljubljana, Ljubljana)

Gábor V. Szabó (Eötvös Loránd University, Budapest)

Tivadar VIDA (Eötvös Loránd University, Budapest)

Technical editor

Gábor VÁcZI

Proofreading

Eszter TímÁr

Strobe DrIVER

Borbála MoHÁcsI

Fruzsina NÉMETH

Eli J. S. WeAVERDYCKE

Aviable online at http://ojs.elte.hu/dissarch

Contact: dissarch@btk.elte.hu

ISSN 2064-4574 (online)

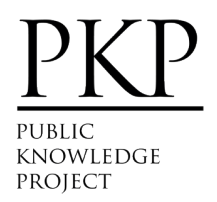

(c ELTE Eötvös Loránd University, Institute of Archaeological Sciences

Layout and cover design: Gábor Váczi

Budapest 2021 


\section{CONTEnTs}

\section{ARTiCles}

Attila PÉNTEK - Norbert FARAgó

Palaeolithic and Mesolithic assemblages from Tunisia

Attila PÉNTEK - Norbert FARAGó

Some remarks on a German chipped stone lithic assemblage of uncertain origin in the collection of the Institue of Archaeological Sciences, Eötvös Loránd University

László Gucsi

Technological observations on a Late Copper Age ceramic assemblage

from Hódmezővásárhely-Kopáncs-Olasz-tanya, Hungary

János Gábor TARBAY

101

A Koszider Period Sword from Tornyospálca-Sírkútgaz (Szabolcs-Szatmár-Bereg County, Hungary)

Ábel GARCZIK

Dolia in the Middle La Tène Period of the Carpathian Basin in the light of new finds from Perkáta-Nyúli-dűlő

Lajos JuHÁsz

An exceptional Sarmatian cast medallion with star and crescent

Gabriella G. DeLBó

New data on the Pannonian glazed casserole handles

Csilla SÁró

The fibula production of Brigetio: Model, semi-finished products, and failed castings

Anita BENES

New data on the capacity of the Roman aqueduct of Brigetio

Melinda SzABó

Status or Role? Differences between the Social Status and Role in Brigetio

Krisztina HoppáL

Roman engraved gems from Southeast Asia 


\section{FiELD REPORTS}

Bence SIMON - Ferenc BARNA

Another barrel-lined well a road section and late Roman graves from Brigetio

Rita RAKONCZAY

Trial excavations in mediaeval churches of Kishartyán, Kisterenye, Mátranovák and Szuha in Nógrád County 2021

\section{Thesis Review Articles}

Tamás KEszi

The change of the pottery style of the Mako and Nagyrév cultures in the Early Bronze Age:

The settlement in Iváncsa-Lapos

Linda Dobosi

Building techniques and building materials in Brigetio:

With the virtual reconstruction of House I/a of the civil town of Brigetio

Csilla SÁRó

Tradition and Romanization by the attire of the Eraviscus tribe 


\title{
Palaeolithic and Mesolithic assemblages from Tunisia
}

\author{
Attila PÉntek \\ Independent researcher \\ attila.pentek@yahoo.com
}

\author{
Norbert FARAgó \\ Institute of Archaeological Sciences, \\ Eötvös Loránd University \\ norbert.farago@gmail.com
}

Received 21 November 2021 | Accepted 7 December 2021 | Published 2 March 2022

\begin{abstract}
With the following short review, we would like to remember our departed German friend and archaeologist Peter Nierling. He conducted several field trips in North Africa, Algeria, Lybia, and Tunisia, and on two occasions, in 1997 and 1998, one of us (A. P.) accompanied him. During these travels, field surveys were carried out mainly in the region of Gafsa. In the wider vicinity of the classical Paleolithic/Mesolithic sites of El Mekta (de Gafsa) and Lalla (de Gafsa), several unknown archaeological sites and find spots were localized. After these trips, one of the authors (A. P.) received a relatively great assemblage of various content from Peter Nierling to enrich the Palaeolithic and Mesolithic collections of the Hungarian stone tool research. Although the Palaeolithic and Mesolithic of North Africa is not our specialization, below we give a brief review of the assemblages.
\end{abstract}

Keywords: Middle Palaeolithic, Upper Palaeolithic, Mesolithic, North Africa, lithics

To the memory of Peter Nierling (1927-2017)

$$
\text { بارغألى اولماعتو ناوخ إلىاك اورشاعت }
$$

"Get together like brothers, but work together like strangers."

Arabic Proverb

\section{Introduction}

With the following short review, we would like to remember our departed German friend Peter Nierling, who was an exceptional figure in German archaeology. He carried out fruitful excavations twice at the Mesolithic site of Bebensee (North-Germany, Province of Schleswig-Holstein) he had located himself. Unfortunately, he never published the results of these excavations. Thereafter, due to existential pressure, he took over his father's small enterprise of lightning technology, he could deal with Palaeolithic and Mesolithic research only as a hobby.

At the beginning of the 2000s, he donated his large collection of Mesolithic artefacts originating mainly from the Province of Schleswig-Holstein to the Museum of Schleswig. He travelled to East Africa, mainly to Kenya about 20 times, organising collecting expeditions on his own. The collected lithic material, containing mostly Oldowan and Acheulean artefacts, was exhibited in Germany on a travelling exhibition, and he finally donated it to the Archaeological Institute of Cologne. He also visited North Africa, Algeria, Lybia, and Tunisia several times. On two occasions, in 1997 and 1998, one of the authors (AP) accompanied him. During these travels, field surveys were carried out mainly in the region of Gafsa. In the wider vicinity of the classical Palaeolithic/Mesolithic sites of El Mekta (de Gafsa) and Lalla (de Gafsa), several unknown archaeological sites and find spots were localized. After these travels, one of the authors (AP) received a relatively large assemblage of 
various content from Peter Nierling to enrich the Palaeolithic and Mesolithic collections of the Hungarian stone tool research. ${ }^{1}$ Although this part of North Africa's human history is not our specialisation, below we give a brief review of the assemblages and their wider cultural context.

The classical scientific literature dealing with the Palaeolithic and Mesolithic of North Africa has served as a framework for the review of different cultures and industries. ${ }^{2}$ In the structural build-up, we obtained invaluable help from the paper of Le Quellec. ${ }^{3}$ Due to the nature of the theme, there is sometimes a disturbing confusion between the English and French geographical names. Whenever possible, we tried to give both variants. In our overview, we intend to follow a chronological order, although nearly every location yielded lithic artefacts from various periods.

\section{Description of the sites and lithic assemblages}

Gafsa (Qafșah), originally called Capsa in Latin, is the capital of southwest Tunisia and is both a historical oasis and home of the mining industry, thus occupying a remarkable geographical and strategic position. The town, built on a rounded eminence 1,150 feet high, dominates the ravine of the Wadi Bayech ${ }^{4}$ between the mountainous massif of the Jebel Orbata in the S.E., the Jebel El Assala and Jebel Ben Younes in the N.W., and therefore the route between the steppes of Central Tunisia and the Chott country.

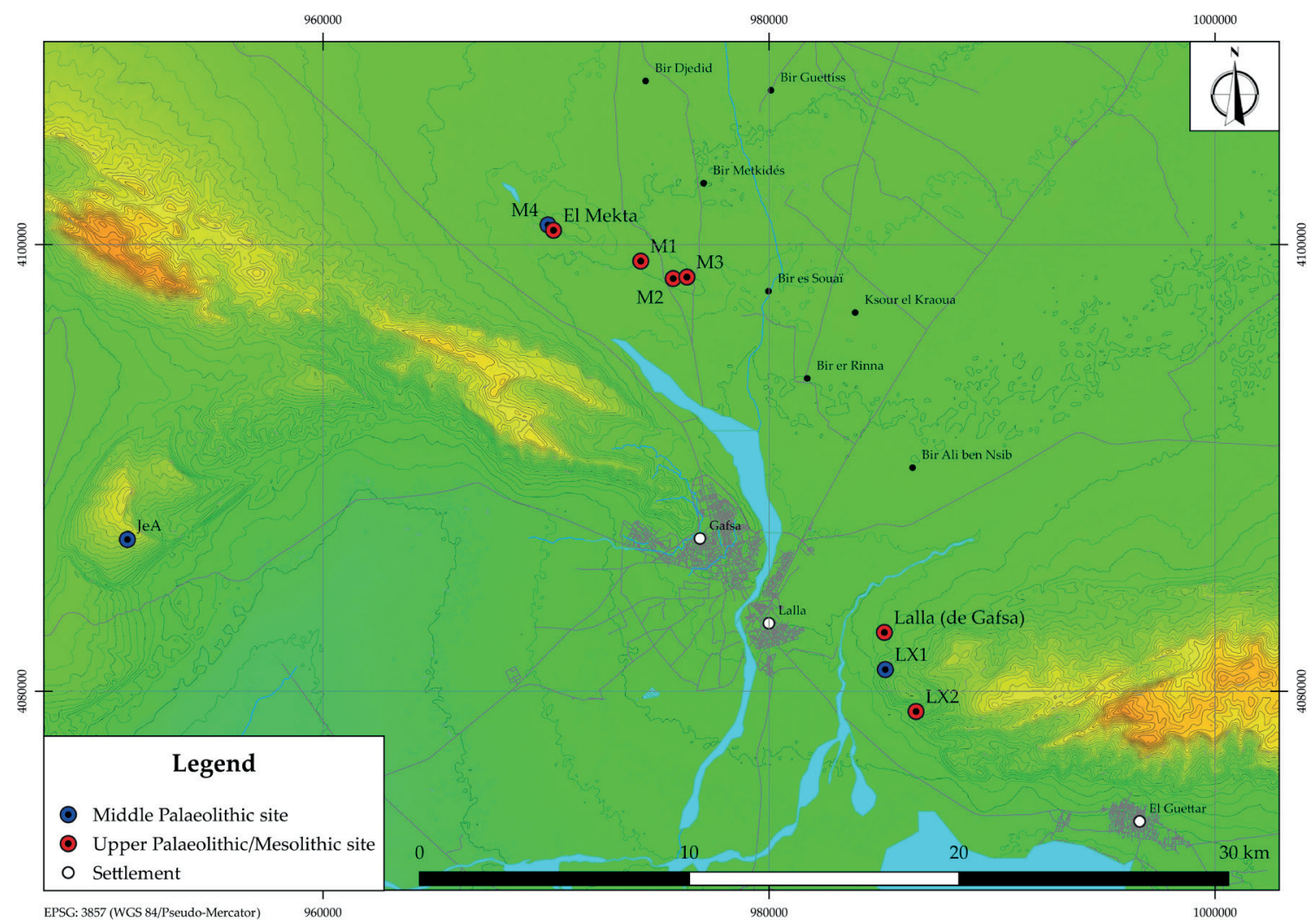

Fig. 1. Environment of Gafsa with Palaeolithic/Mesolithic sites. Loránd University to help students' training concerning Palaeolithic and Mesolithic stone tools.

CAMPS 1974; NeHREN 1992.

LE QUELLEC 2014.

Oued Baiech; a wadi (oued) is a valley or ravine, bounded by relatively steep banks, which becomes a watercourse in the rainy season. 


\section{Jebel el Ali}

West of Gafsa, a slightly curved range of mountains drags in a length of about $15 \mathrm{~km}$ in a north-east-south-west direction. At the southwestern end of this range, we find the mountain Jebel el Ali. Its highest peak is the Kāf ad Dekouane with an elevation of 696 m above sea level.

The open-air Palaeolithic site is situated on the right side of the Gafsa-Moulares road, on a southern terrace of the mountain. On the surface stretching some acres, mingled lithic material of Acheulean, Mousterian and Aterian characteristics was collected (Fig. 1, feA).

The presence of an Acheulean hand-axe of the amygdaloid form should be stressed (Fig. 2). Its measures are $166 \times 89 \times 33 \mathrm{~mm}$. It is symmetric to the longitudinal axis and has a plano-convex cross-section. The base is rounded. The elaboration of the side edges is somewhat different. The distal part of the left edge has a defined zig-zagged line, the proximal part is unworked. On the other hand, the entire right edge bears only sporadic traces of elaboration and can be regarded practically as straight. On the ventral face, the elaboration is confined to minimal thinning activity; for this reason, the blank of the hand-axe might have had a tabular form. Near the tip, on the left side of the ventral face, there is some small damage, a possible pitting during scrolling. Despite this fact, the raw material of the hand-axe cannot be determined conclusively. It is presumably flint, but the entire surface is heavily eroded and covered by a thick weathering crust of dirty brownish-yellow colour (amber). However, it is highly questionable whether this intensive weathering can be regarded as an age factor.

The other remarkable artefact is an alternately retouched macro-blade (Fig. 3,2). Its measures are $147 \times 41 \times 20 \mathrm{~mm}$. It has a single arris and a slightly asymmetric form. The left side edge is approximately straight, its distal part is retouched in a length of $30 \mathrm{~mm}$. From this on, the ventral face shows traces of inverse

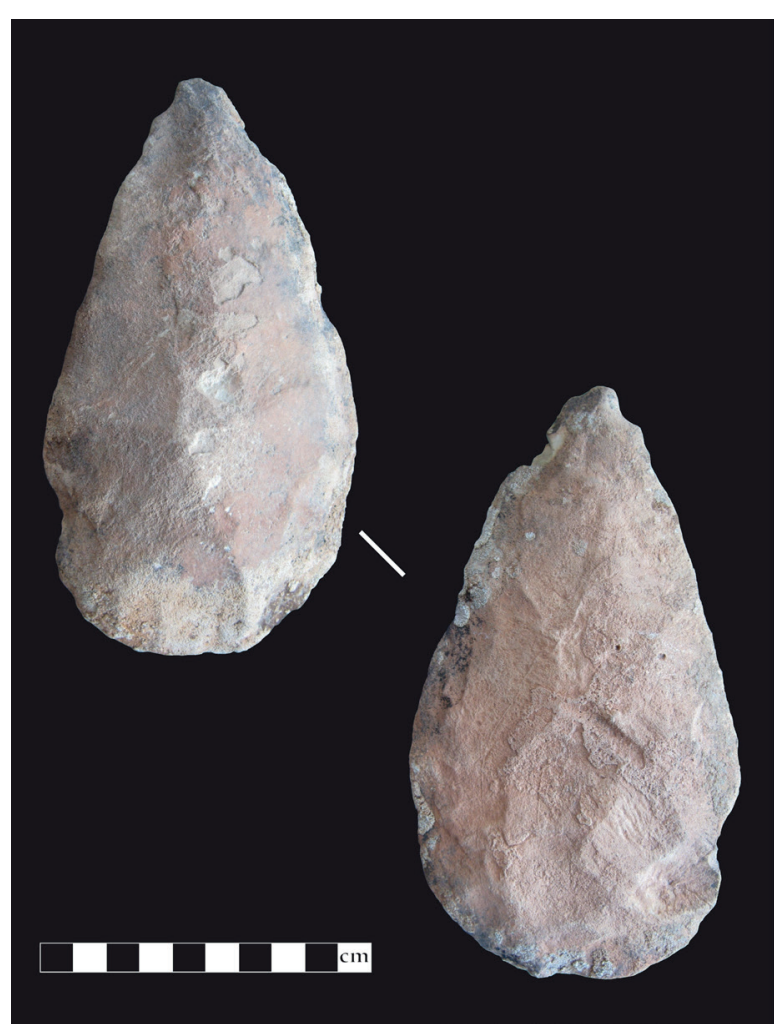

Fig. 2. Hand-axe from Jebel el Ali.

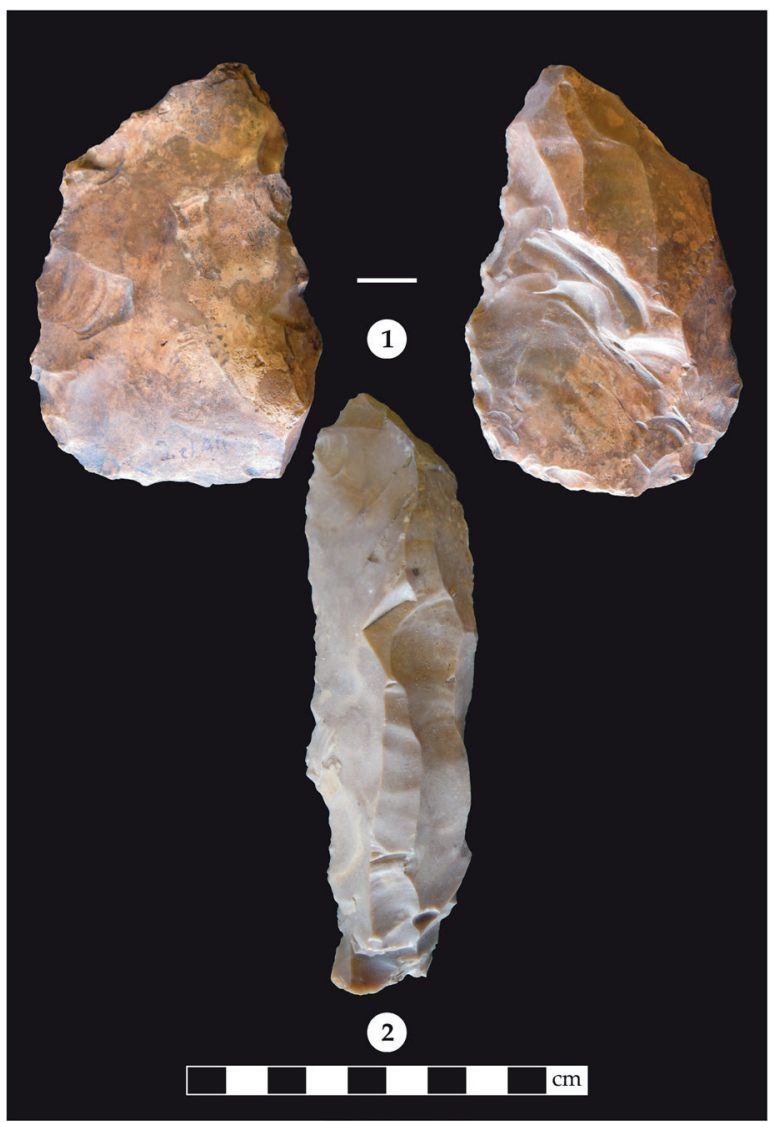

Fig. 3. Selected Middle Palaeolithic artefacts from Jebel el Ali. 1 - side-scraper, 2 - macro-blade. 


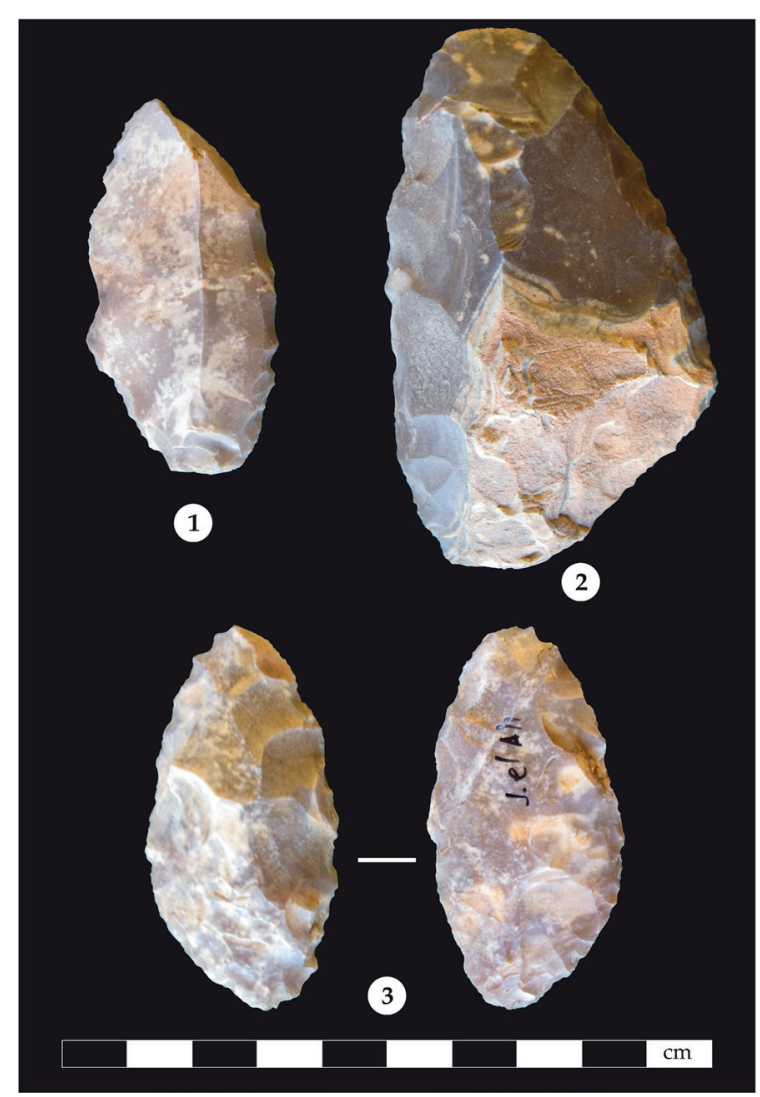

Fig. 4. Selected Middle Palaeolithic artefacts from Jebel el Ali. 1 - side-scraper made on elongated blade, 2 - side-scraper, 3 - bifacial artefact.

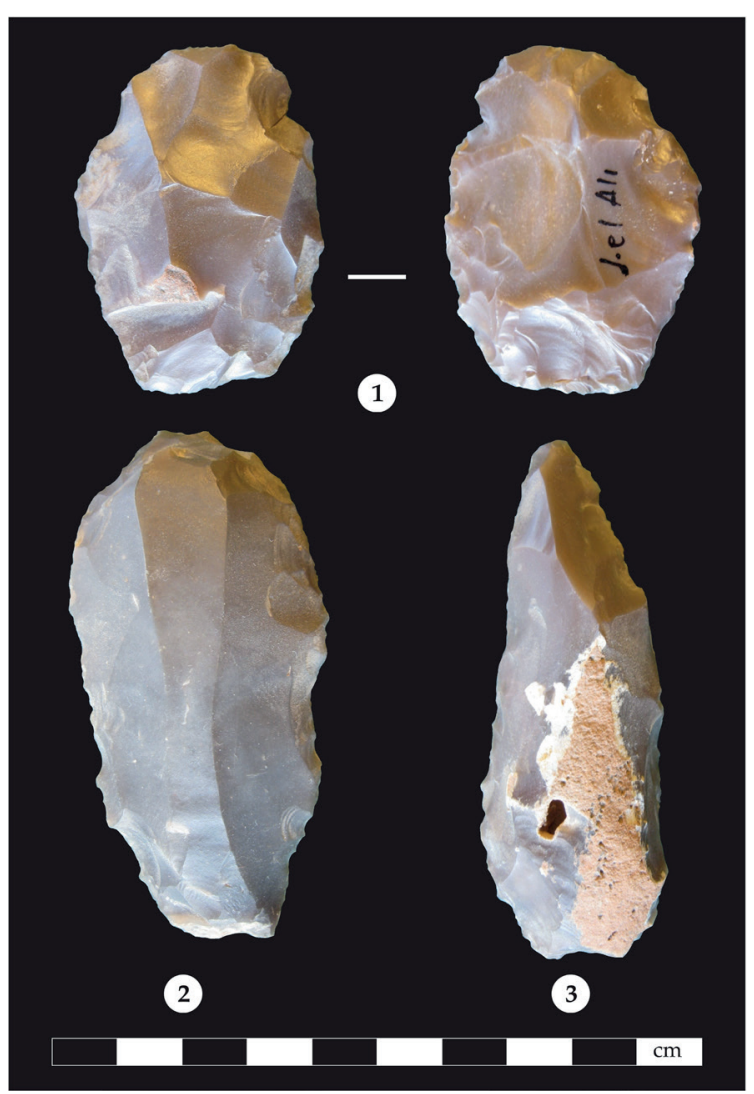

Fig. 5. Selected Middle Palaeolithic artefacts from Jebel el Ali. 1 - bifacial artefact, 2 - end-scraper on blade, 3 - laterally retouched blade.

retouch in a length of $65 \mathrm{~mm}$. Its butt is prepared, the bulb is well pronounced and is not lipped. Presumably, the "hard hammer direct percussion" technique had been used by the removal. The scar pattern on the dorsal face is unipolar, i.e., the flake scars start from the proximal end. On the proximal end, there are traces of several hinged removals. The raw material of the artefact is Upper/ Late Cretaceous Senonian flint of greyish colour, the surface is relatively fresh, unpatinated. Due to some analogies of the eponymous Aterian site Oued Djebbana (Bir el Ater), ${ }^{5}$ this macro-blade can probably be attributed to the Aterian. Among the Aterian characteristic bifacial artefacts Fig. 4,3 and Fig. 5,1, end-scraper made on a blade (Fig. 5,2), as well as the bilateral retouched pointed tool made on a blade have to be noted (Fig. 5,3).

\section{Lalla (de Gafsa)}

The Wadi el Maleh is situated east of Gafsa, at the western foothill of the Jebel Orbata Mountain. The wadi has its mouth in Chott el-Gharsa, and it is almost a river because of a series of wadis in the area between Gafsa and Tozeur, forming a "right-of-way" for a distance of 70 kilometres. Decreasing precipitation in the area means that it does not carry water, except in the case of rain, usually occurring during the fall and winter. The hilly area between the western foothill of the Jebel Orbata and the Wadi el Maleh is dissected by several watercourses. On the left bank of the Wadi el Melah, there is the classical site of Lalla de Gafsa. ${ }^{6}$ This find complex of the so-called Horizon Collignon will be brought into strict connection with the Late Upper Palaeolithic Iberomaurusian 


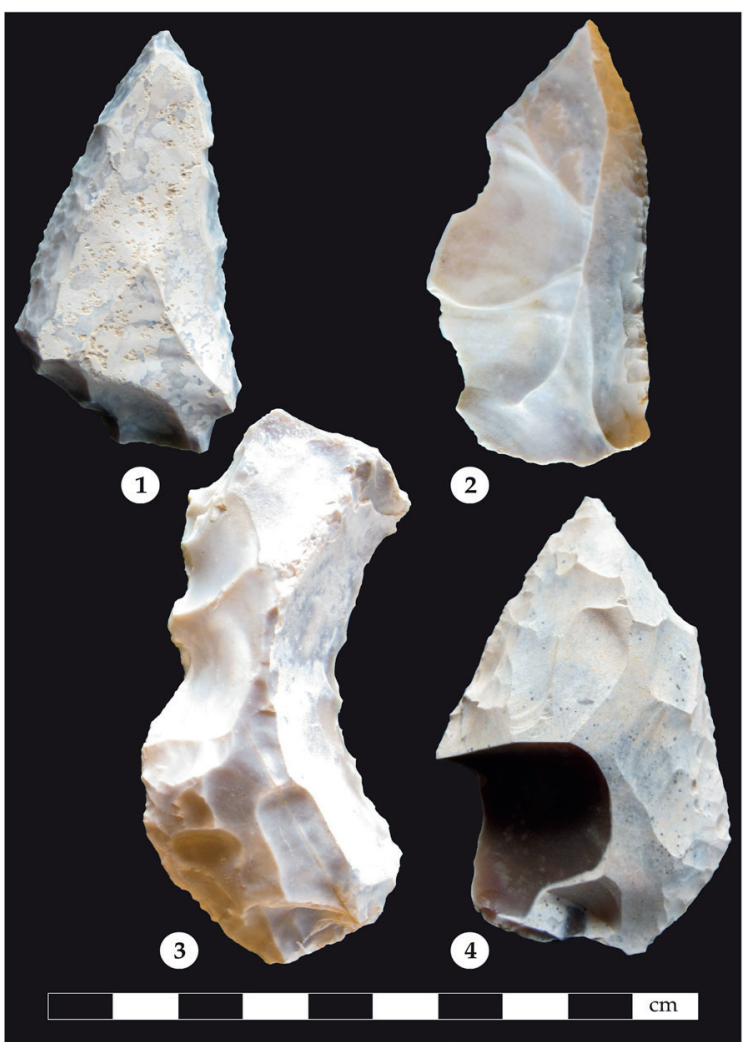

Fig. 6. Selected Middle Palaeolithic artefacts from site L5 near Lalla. 1-4 - side-scrapers.

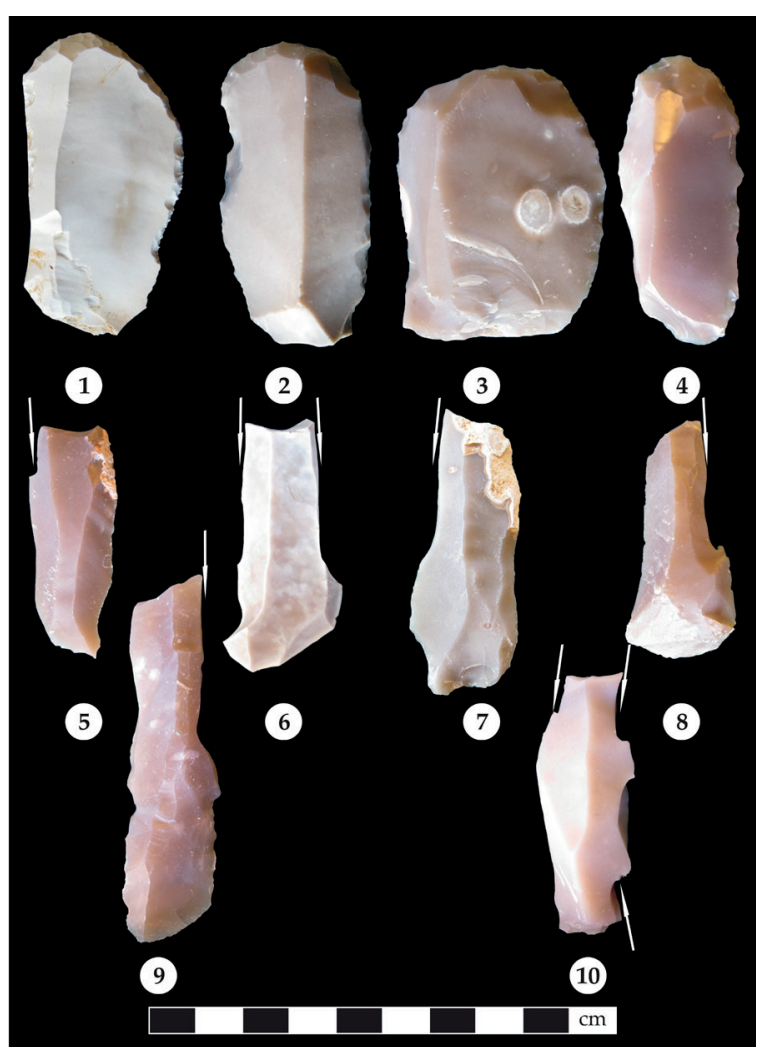

Fig. 7. Selected Upper Palaeolithic artefacts from site L5 near Lalla. 1-4 - end-scrapers, 5-10 - burins.

industry. Numerous doubts have arisen about the results of the excavation and the chronological and cultural classification of the assemblage of Lalla de Gafsa. According to R. Nehren, ${ }^{7}$ Ouchtata bladelets show a high frequency at the site that appears to be related to the "Ouchtata facies" of the Iberomaurusian in Tunisia.

However, only sporadically and in relatively smaller scattered find spots can we find even strayed lithic artefacts of a Middle Palaeolithic character (Fig. 1, LX1). These artefacts may have been washed down from a somewhat higher level of the foothill of the Jebel Orbata. Among them, the side-scrapers are clearly dominant.

One example is a convergent scraper (Fig. 6,4) is made on a slightly déjeté flake $(66 \times 43 \times 12 \mathrm{~mm})$. On its left side, we see recent thermal damage. This frequently occurs due to variations in temperature combined with humidity. Another piece is a denticulate-concave side-scraper combination (Fig. $6,3)$ is made on a rightish blank $(79 \times 34 \times 13 \mathrm{~mm})$. Very similar artefacts have been published from open-air Aterian sites in the Djanet region (Tassili n'Ajjer, Algeria). ${ }^{8}$

On the left riverbank of the Wadi el Melah, stretching about 5-7 kilometres long, two larger and nine smaller artefact concentrations could be localized, mainly with Iberomaurusian and Typical Capsian lithic material, and a third larger site with predominantly Neolithic artefacts. In Fig 1. Lalla (de Gafsa) denotes the classical site of Lalla de Gafsa, LX1 and LX2 denote the approximate positions of the two larger sites L5 and L7.

In Fig. 7, there are selected end-scrapers and burins made on truncation from the site of L5. The end-scrapers are morphologically varied: some of them are made on a regular blade (Fig. 7,2) or on

7 NEHREN 1992

8 NeHren 1992, Taf. 30. 


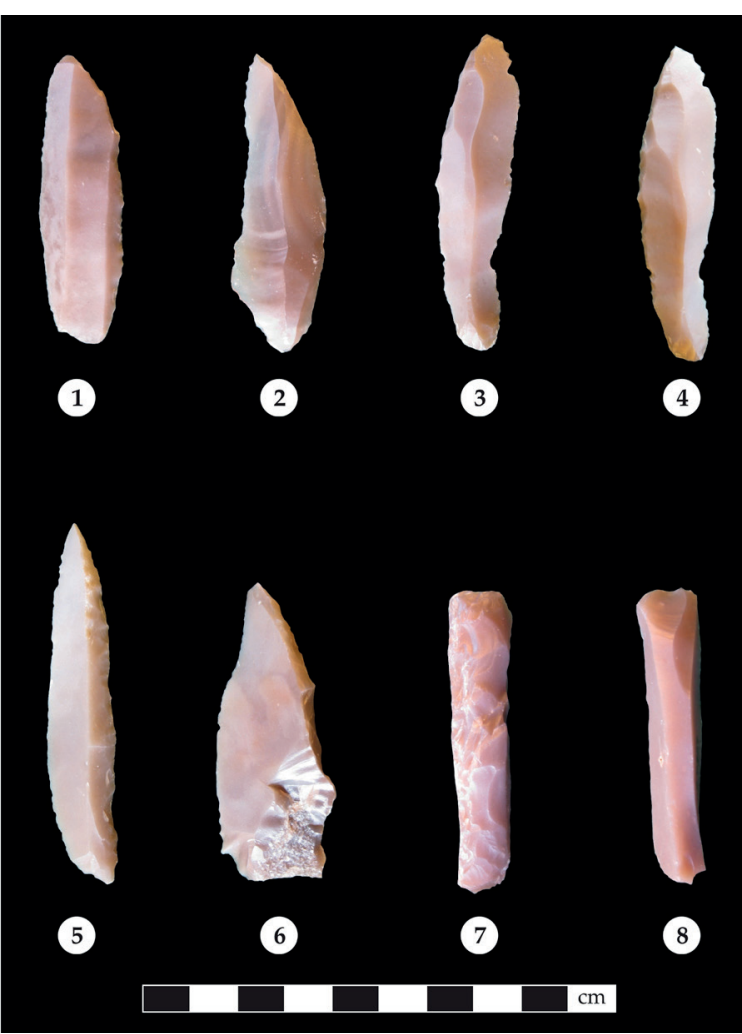

Fig. 8. Selected Upper Palaeolithic artefacts from site L5 near Lalla. 1-4 - unretouched blades, 5, 7 backed blades, 6 - retouched blade, 8 - burin spall.

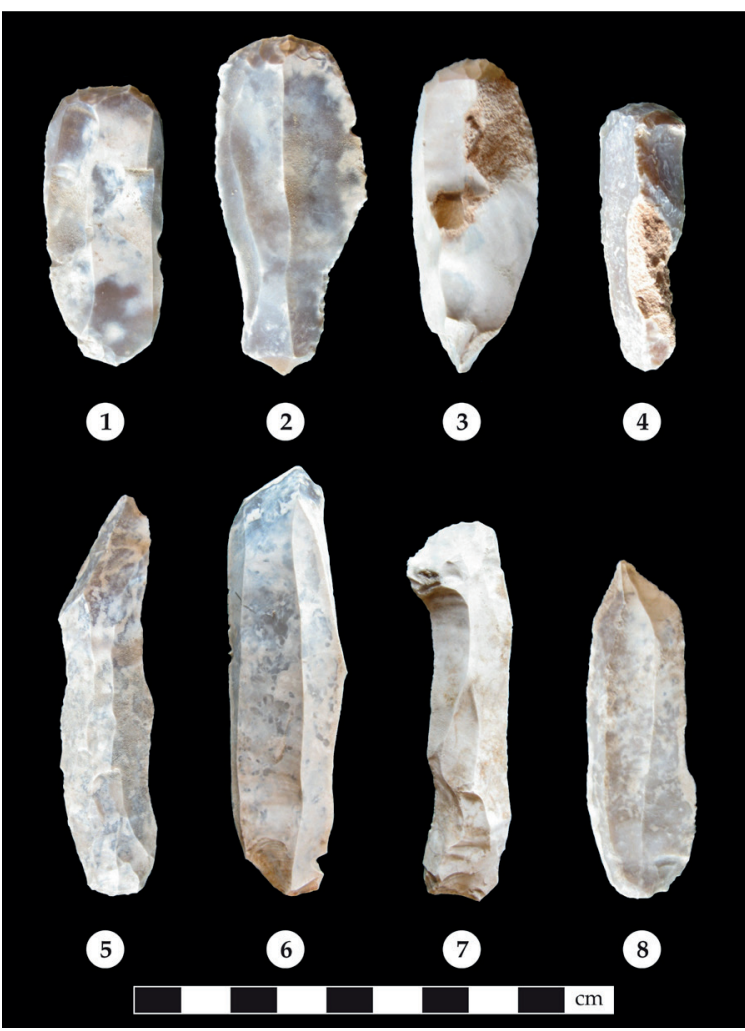

Fig. 10. Selected Upper Palaeolithic artefacts from site L7 near Lalla. 1-4 - end-scrapers, 5-8 - unretouched blades.

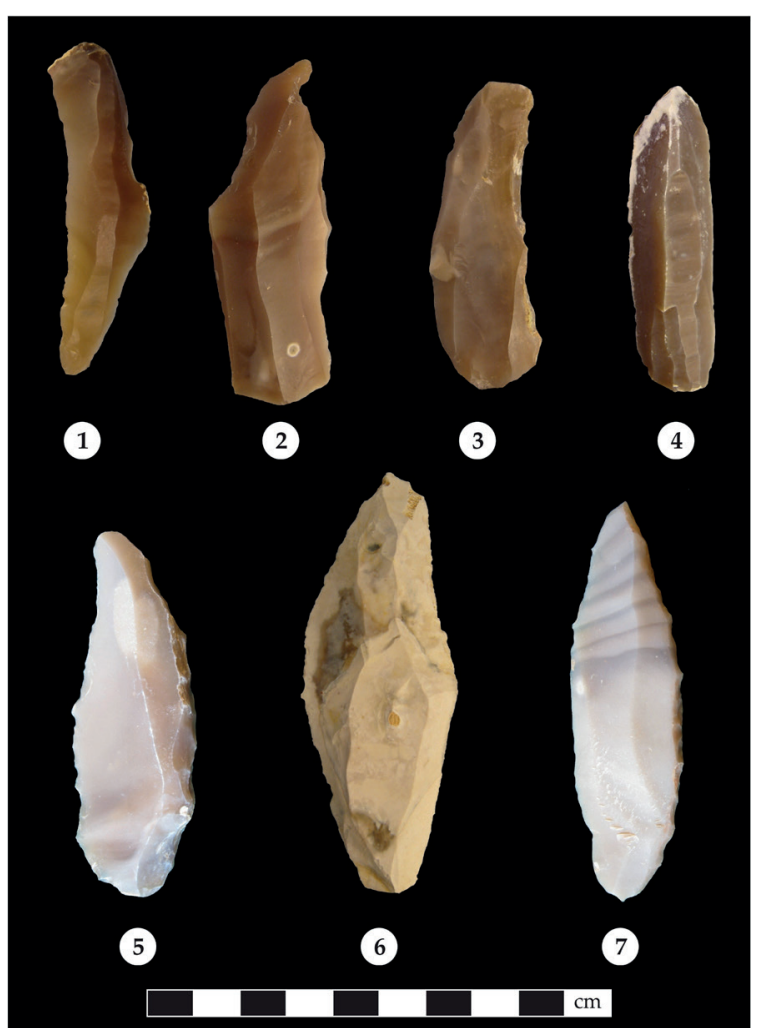

Fig. 9. Selected Upper Palaeolithic artefacts from site L5 near Lalla. 1-4 - retouched blades, 5-7 - backed blades.

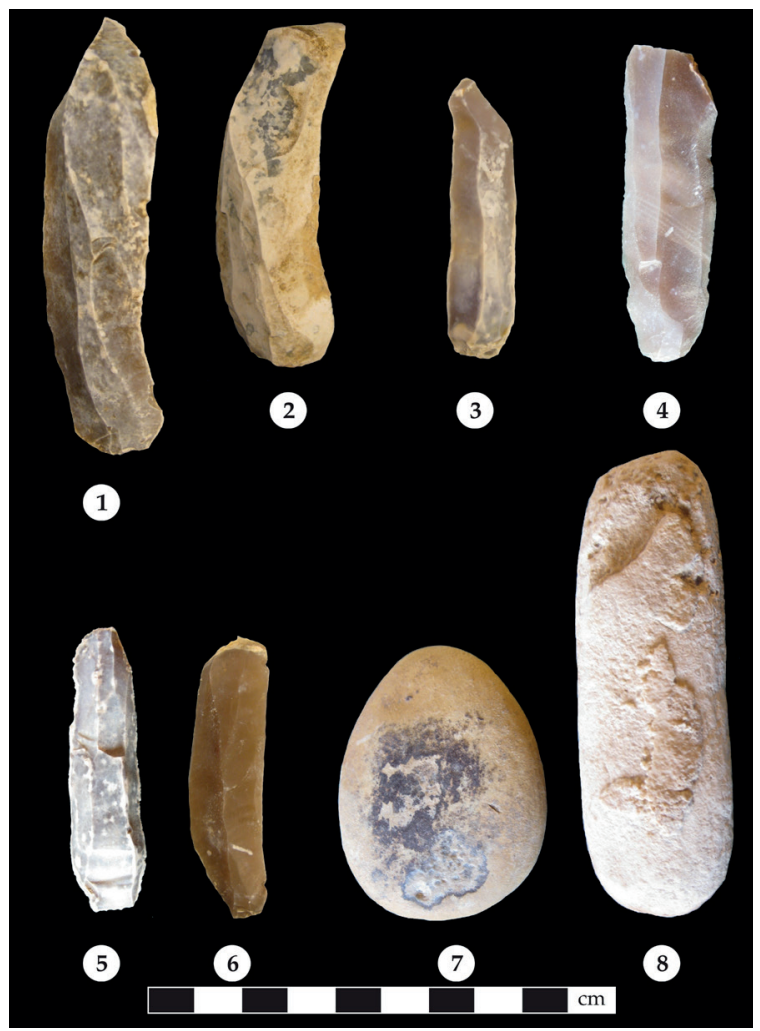

Fig. 11. Selected Upper Palaeolithic artefacts from site L7 near Lalla. 1-6 - unretouched blades, 7 - pestle with ochre remnant, 8 - retoucher. 
an irregular blade (Fig. 7,1,4) or a flake (Fig. 7,3). Generally, the end-scrapers made on a flake are wide, chunky exemplars. The burins on truncation are always made on an elongated blank, which can be either a blade or flake, in some cases the blank can even be an amorphous raw material fragment. There are single, double, and multiple burins. There seems to be no tendency in the typical length of the burin spalls, but there are some extraordinarily long ones (Fig. 8,8).

In Fig. 9, there are blades from the site of L5. In the upper row, the first three blades have a highly irregular form. Blades with a stressful twisted profile are very frequent (Fig. 9,1,3). In the lower row, there are two backed blades (Fig. 9,5,7). The distal ends of the large blade in Fig. 9,6 are retouched. Unfortunately, due to various taphonomical events, it is damaged.

In Fig. 8, there are mainly various retouched or backed microliths from the site of L5. Based on the typology list of Tixier, ${ }^{9}$ morphologically they are relatively common forms.

In Fig. 10, there are selected end-scrapers and blades from the site of L7. In the total assemblage of this site, all end-scrapers are exclusively made on a blade of a regular form. Among the blades, there are relatively large examples, exceeding up to $100-110 \mathrm{~mm}$. They are frequently twisted, and there are many plunging (outrepassé) blades.

Among the blades of the site, only the middle-sized blades $(60-80 \mathrm{~mm})$ have a regular form, with one or two guiding arrises (Fig. 10,3-6).

Two artefacts from the site deserve special attention. The one is an oval pebble with bruises, with definite traces of striking and breaking of ochre clods (Fig. 11,7). The second is a retoucher made of an elongated limestone pebble (Fig. 11,8).

In Fig. 12 and Fig. 13, there are several microliths from the site of L7. Besides the common forms, there are two special types of Tixier. ${ }^{10}$

The first is Type 47, "Lamella aiguë, à bord abattu rectiligne et base tronquée." ${ }^{11}$ It has a basal truncation (by direct or inverse retouching) forming an acute angle with the backed edge. ${ }^{12}$ Basal truncation (distal or proximal), is often obtained by retouching less abruptly than the back, maybe rectilinear, convex, or slightly concave. It is necessary to insist on the angle formed by the backed edge and the truncation. This angle, with a more or less marked summit, will have to be acute: in fact, a right-angle or obtuse angle would make the piece a right-angled or scalene triangle. The silhouette of some backed microblade and basal truncation may be identical to that of certain triangles; but in these, as in all microliths - except segments, trapezes, or triangles - it is always the largest side that is not retouched. ${ }^{13}$ Two Type 47 microliths from the site of L7 can be seen in Fig. 12,3,5, and a third in Fig. 13,1.

The second special type is Type 49 of the type list, "Pointe du Chacal" (after the eponymous site of "Escargotière du Chacal", Tébessa, Algeria). It is a straight, abruptly backed microblade of a very slender silhouette, whose base has a short truncation adjacent to the backed edge and an opposite longer truncation, obtained by direct retouches. ${ }^{14}$ Two specimens of Type 49 microliths can be seen in Fig. 12,1,6. 


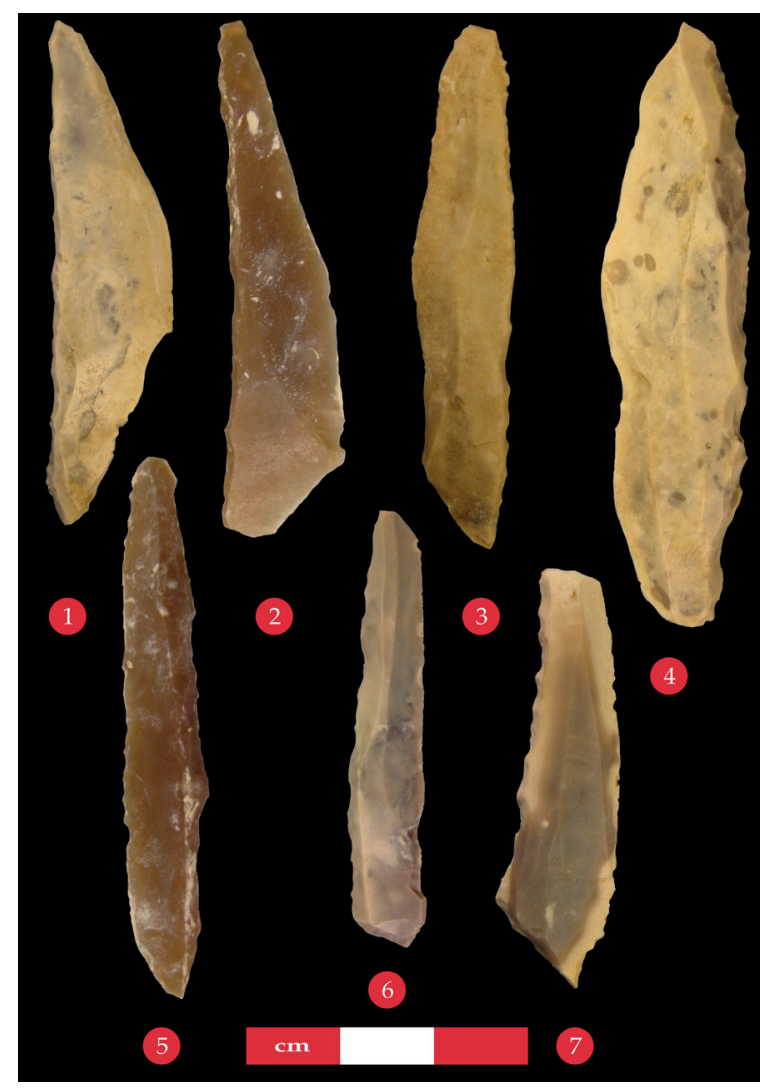

Fig. 12. Selected Upper Palaeolithic artefacts from site L7 near Lalla. 1-7 - microliths.

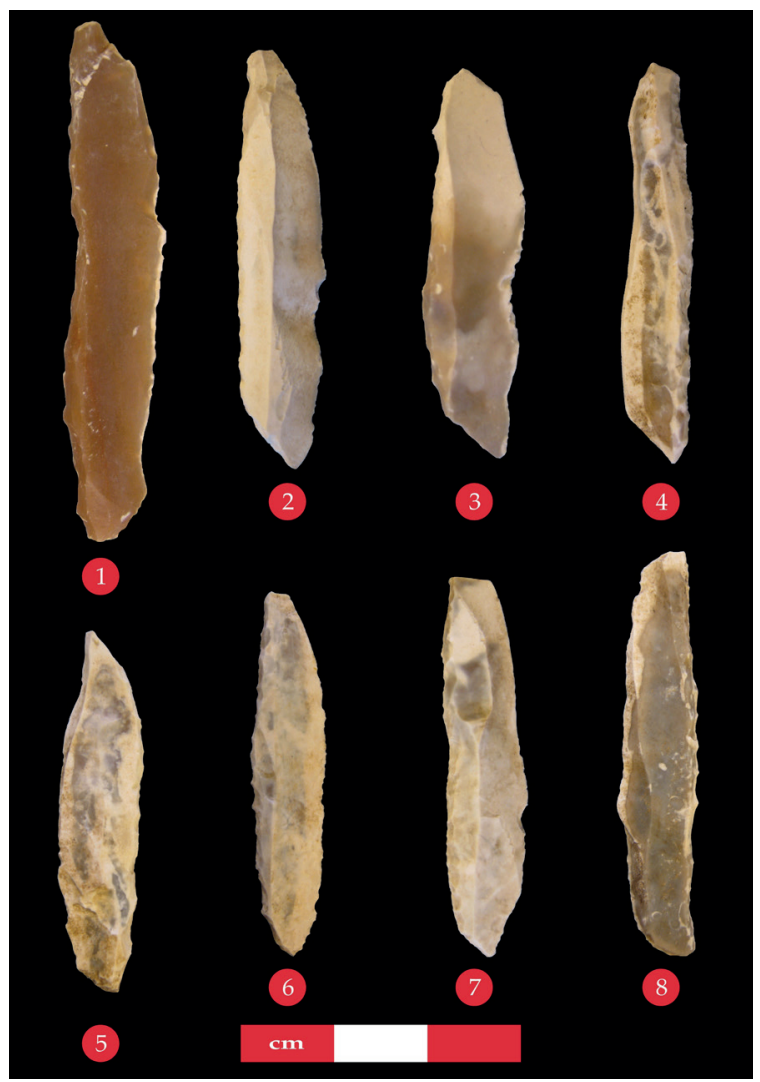

Fig. 13. Selected Upper Palaeolithic artefacts from site L7 near Lalla. 1-8 - microliths.

The microlith in Fig. 12,7 has strong similarities to Type 68 of Tixier: "Lamelle scaléne". ${ }^{15}$ A straightbacked microblade, having an oblique truncation, thereafter forming a well-marked angle to the top; the backed edge and truncation are obtained either by abrupt retouching or, more frequently, by retouching Ouchtata, a portion of the butt that is always preserved..$^{16}$ The piece from Lalla L7 has two backed edges and both ends are truncated; in a sense, it can be regarded as a more sophisticated form of Type 68 .

\section{El Mekta (de Gafsa)}

The tribal area of Awlad Moussa (Oulad Moussa) is situated to the north of the confluence of the two seasonal watercourses Wadi el Kebir and Wadi Sidi Aich, directly in the northern part of Gafsa, which is a depression seasonally overflowed by water. On the south-western verge of the depression the range of hills of El Mekta runs along in the northwest-southeast direction. Smaller sandhills, usually with antique ruins on their tops can be found on its northern verge. ${ }^{17}$ On both sides of the Wadi Sidi Aich and its right tributary (Wadi es Somaa), there are wells. ${ }^{18}$

The Palaeolithic site of El Mekta is located on the above-mentioned range of hills (343' N $8^{\circ} 43^{\prime} \mathrm{E}$ ), about $15 \mathrm{~km}$ north-north-west of Gafsa, on the left side of the Wadi el Kebir, at an altitude of $430 \mathrm{~m}$ above sea level. This is the eponymous site of the Mesolithic Capsian industry. It is composed of a

TIXIER 1963, 113.

TIXIER 1963, 111, Fig. 39,15,16.

Henchir Kreriba, Henchir Gorguiba; henchir is an Arabic word meaning "farm with ruins".

Bir Djedid, Bir Guettiss, Bir Metkidés, Bir Souaï, Bir er Rinna; bir is the most comprehensive Arabic word for "well". 
Typical Capsian and an Upper Capsian sequence, which may provide further insights into Capsian technological specificities, their evolution, as well as territory management, and exchange networks within communities. A short way off northward from the site, there is a Middle Palaeolithic open-air site with unpublished lithic material. In the collection to be reviewed, there are several Acheulean and Mousterian artefacts originating from this open-air site (Fig. 1, Fig. 14, M4).

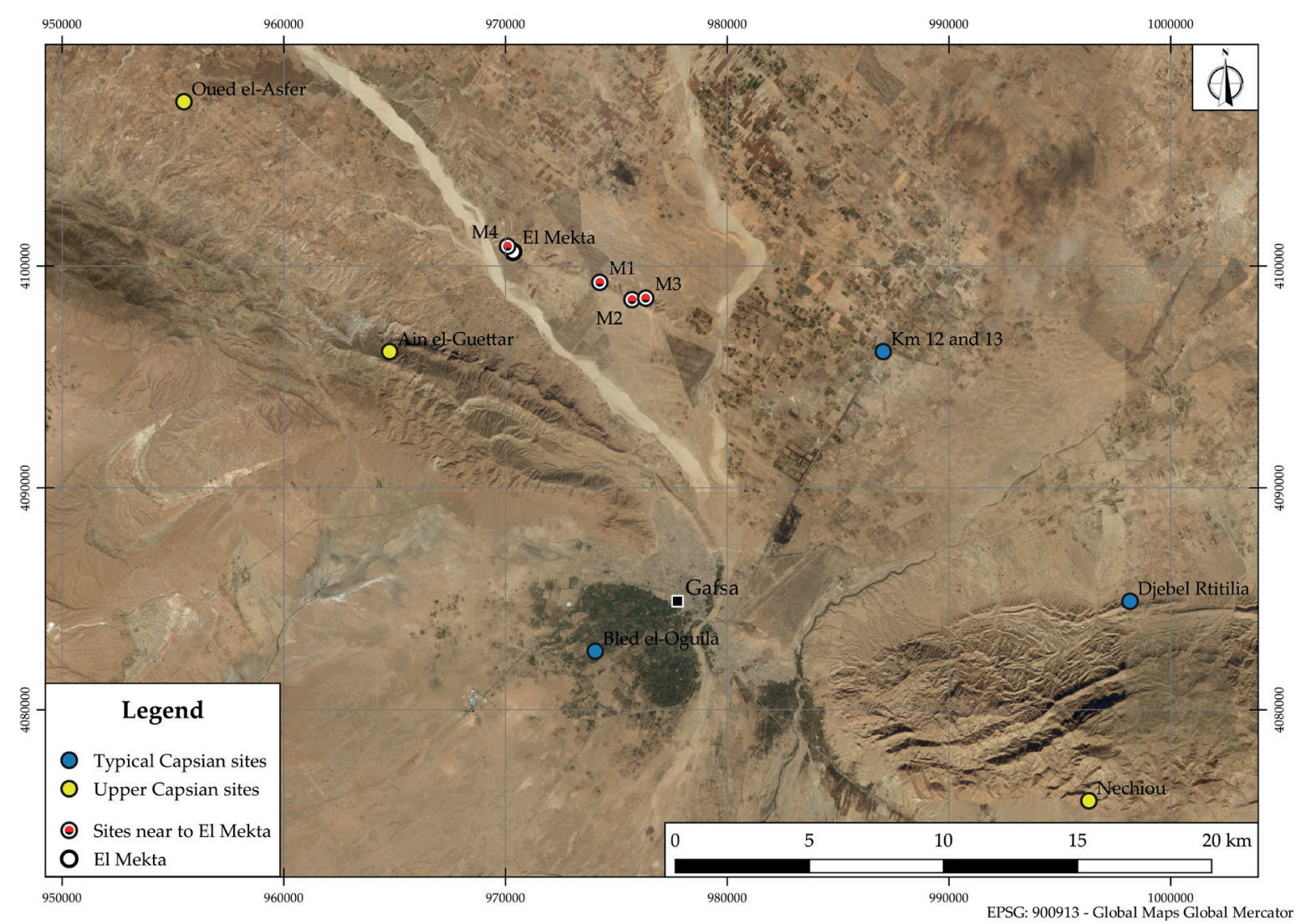

Fig. 14. Capsian sites in the environment of Gafsa.

In this varied collection, the diverse hand-axes and side-scrapers are dominant; Mousterian points are also present, while the usage of the Levallois technique is obvious. From the Levallois cores, the presence of a point core of sub-triangular form should be emphasized (Fig. 15,3). Its measures are $105 \times 72 \times 29 \mathrm{~mm}$. It has a clear resemblance to the so-called Nubian Type 2 cores.

The lithic assemblage, belonging to the Typical Capsian and collected around the classical site of El Mekta (Fig. 14, M4) is relatively small.

Besides the end-scrapers, it contains several large angular burins (Fig. 16). Most burins are double and all of them, without exception, are made on a truncation. There is a great number of prepared pyramidal or mitred microcores (Fig. 17) and microliths (Figs 18-19) as well, which may possibly be attributed to the Upper Capsian. The micro-burin technique is well represented; both the distal (Fig. 19,3) and proximal (Fig. 19,4) micro-burins are present. This Upper Capsian assemblage is dominated by bladelet production. Its main technological characteristic is the application of the pressure technique, which requires the preparation of sophisticated mitred cores. ${ }^{19}$ 


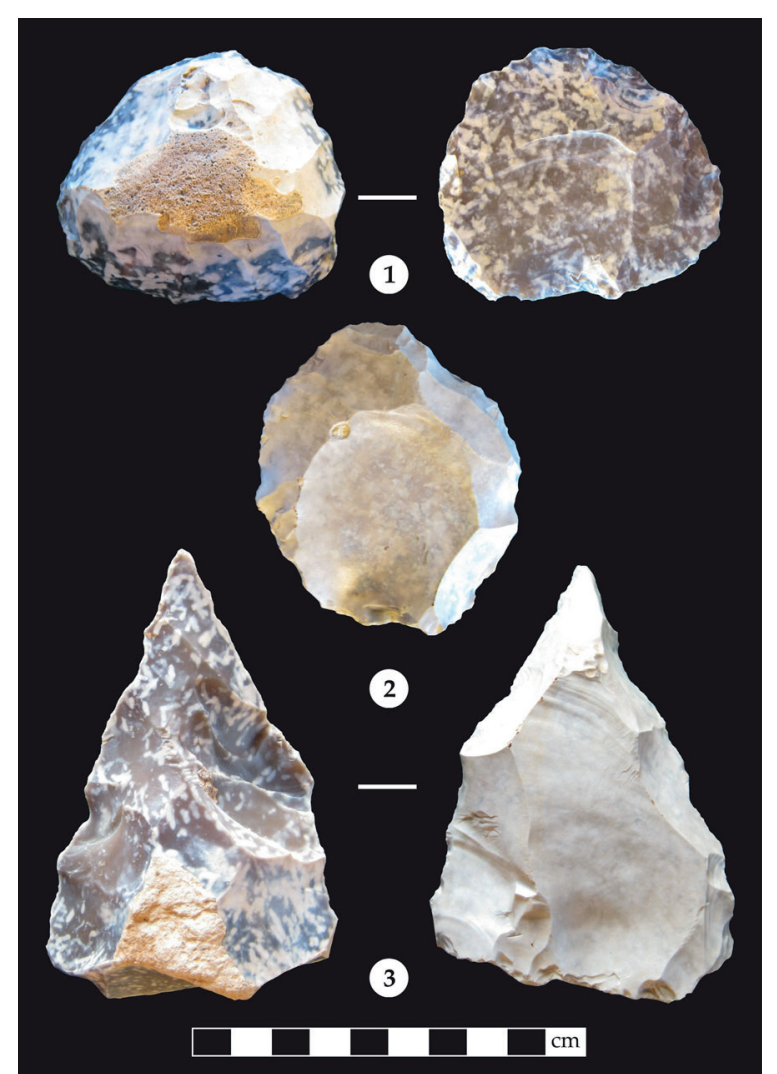

Fig. 15. Selected Middle Palaeolithic artefacts from site M4 near El Mekta. 1-3 - Levallois cores.

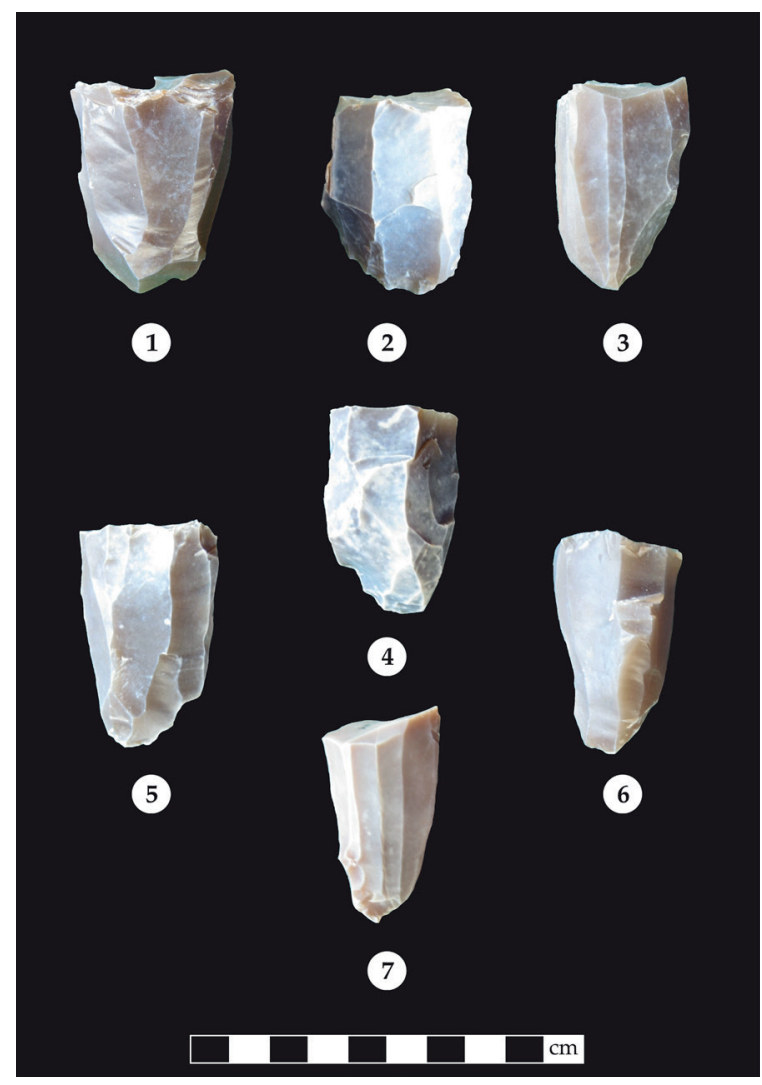

Fig. 17. Selected Mesolithic artefacts from site M4 near El Mekta. 1-7 - cores.

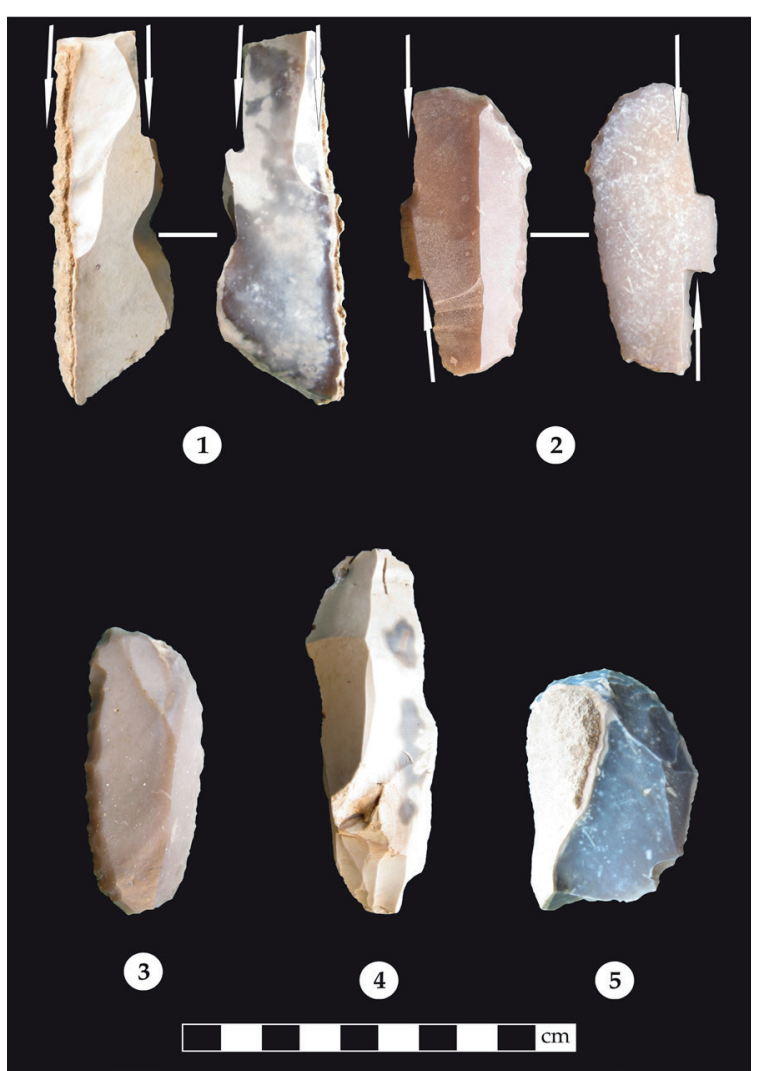

Fig. 16. Selected Mesolithic artefacts from site M4 near El Mekta. 1-2 - burins, 3-5 - end-scrapers.

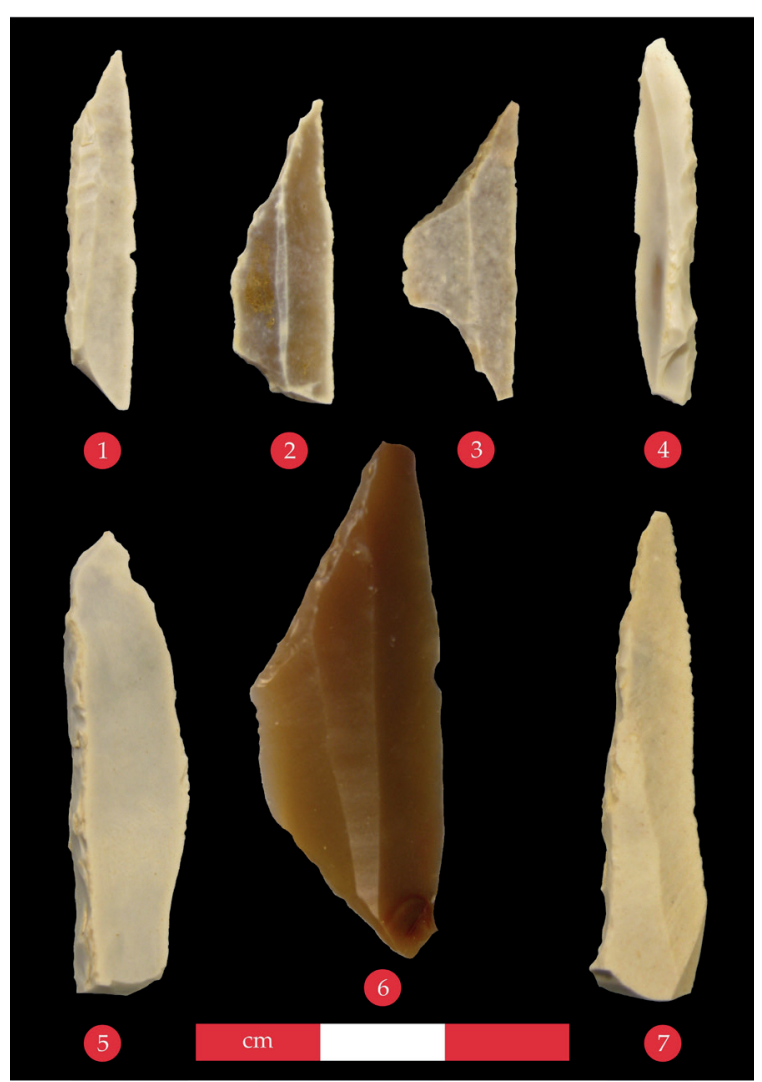

Fig. 18. Selected Mesolithic artefacts from site M4 near El Mekta. 1-7 - microliths. 
In Fig. 18 and Fig. 19, there are some microliths from the site of M4. Besides the common backed forms, which are at the same time rather hard to classify, there are two special types of Tixier. ${ }^{20}$

The first type is Type 77 of the type list ("Lame ou lamelle denticulée"). ${ }^{21}$ It is a blade or microblade with several notches, at least two of which are adjacent (Fig. 19,5).

The second one is Type 87 of the type list ("Trapèze a deux côtés concaves")22 (Fig. 18,3, Fig. 19,1,2). Trapeze with its two concave sides equally or differently inclined on the bases. Trapeze with concave sides comes in two slightly different forms that do not justify two type numbers:

- Trapeze with regularly concave sides ${ }^{23}$

- Trapeze whose sides are, starting from the small base; parallel and perpendicular to this small base for a short distance, then abruptly diverging and rectilinear (or very slightly concave) to the large base. ${ }^{24}$ For this subtype, there is always a great difference between the two bases.

\section{Metkides}

At a short distance from the site of El Mekta, in a south-eastern direction, three smaller archaeological sites or lithic artefact concentrations were located. The sites of M1 and M2 (Fig. 1,15, M1, M2) yielded Typical Capsian lithic artefacts, and the site of M3 (Fig. 1,15, M3) has a small Upper Capsian assemblage containing only microliths.

From both Typical Capsian sites, the site of M1 was not only very rich in lithic artefacts but had a varied toolkit as well. In the toolkit, the large-sized simple or double angular burins made on a truncation were clearly dominant.

The presence of the backed pointed tool (Fig. 20,1) and the double side-scraper (Fig. 20,3) should be considered as rather accidental. From the so-called tool "Couteaux à dos capsiens", ${ }^{25}$ which is Type 37 of the type list of Tixier ("Lame à bord abattu arqué") ${ }^{26}$ a single exemplar was found (Fig. 20,2). According to the definition of Tixier, it is a blade with an arched edge struck by more or less abrupt retouches made either locally or entirely "on the anvil". ${ }^{27}$ Two-sided retouching terminates either in the distal part or in the proximal part of the raw blade because its thickest end had been chosen for a certain purpose..$^{28}$ These retouching "sur enclume" (on the anvil), almost always begin at the meeting point of an arris and the back, which seems to indicate that the piece was placed on the anvil, with the dorsal side turned towards the worker. The contre-coup technique applied is a special case of the (bipolar) anvil technique described by Bordes. ${ }^{29}$ During the blunting of the back, that is while striking the ventral side of the object, small flakes will be removed from the surface that was struck. ${ }^{30}$ This technique produces a very abrupt backed edge.

20 TIXIER 1963.

21 Tixier 1963, 121, 122, Fig. 43,8,12.

22 Tixien 1963, 132; 130, Fig. 47,18,19.

23 TiXIER 1963, 130, Fig. 47,18,20,21.

24 Tixier 1963, 130, Fig. 47,19.

25 Camps 1974, 105, Fig. 24; 117, Fig. 29.

26 TIXIER 1963, 87.

27 TIXIER 1963, 89, Fig. 31,1.

28 TIXIER 1963, 88, Fig. 30,5.

29 Bordes 1947, 16.

30 Tixien 1963, 88, Fig. 30,1,2. 


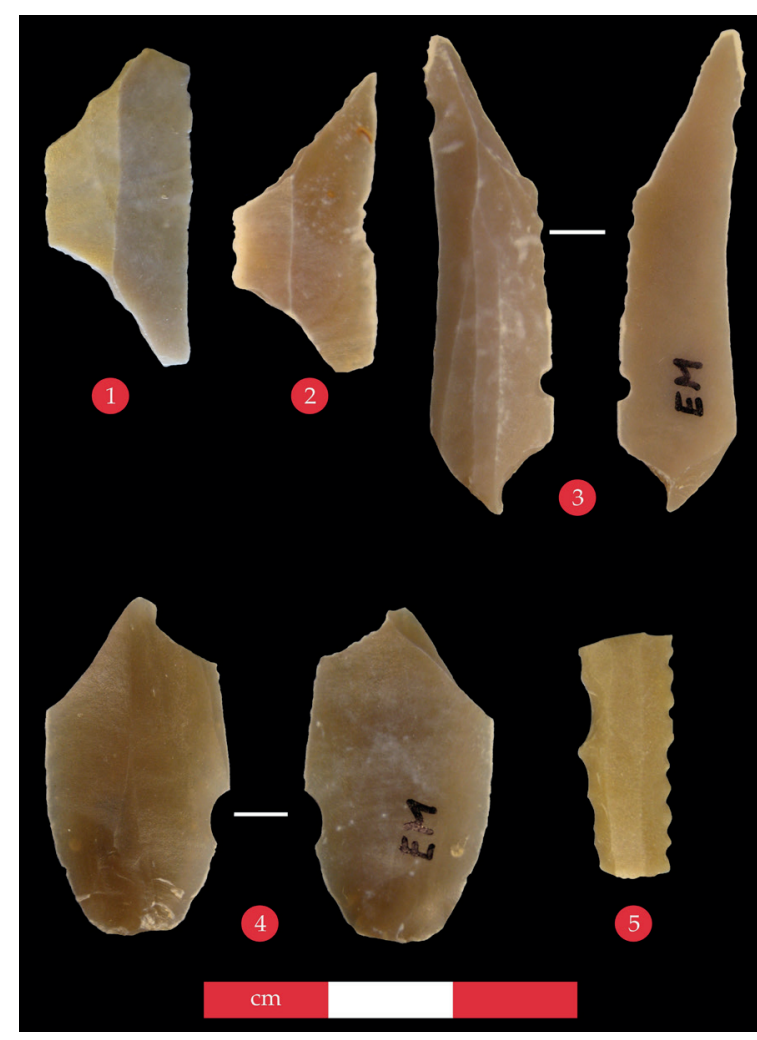

Fig. 19. Selected Mesolithic artefacts from site M4 near El Mekta. 1-2, 5 - microliths, 3-4 - microburins.

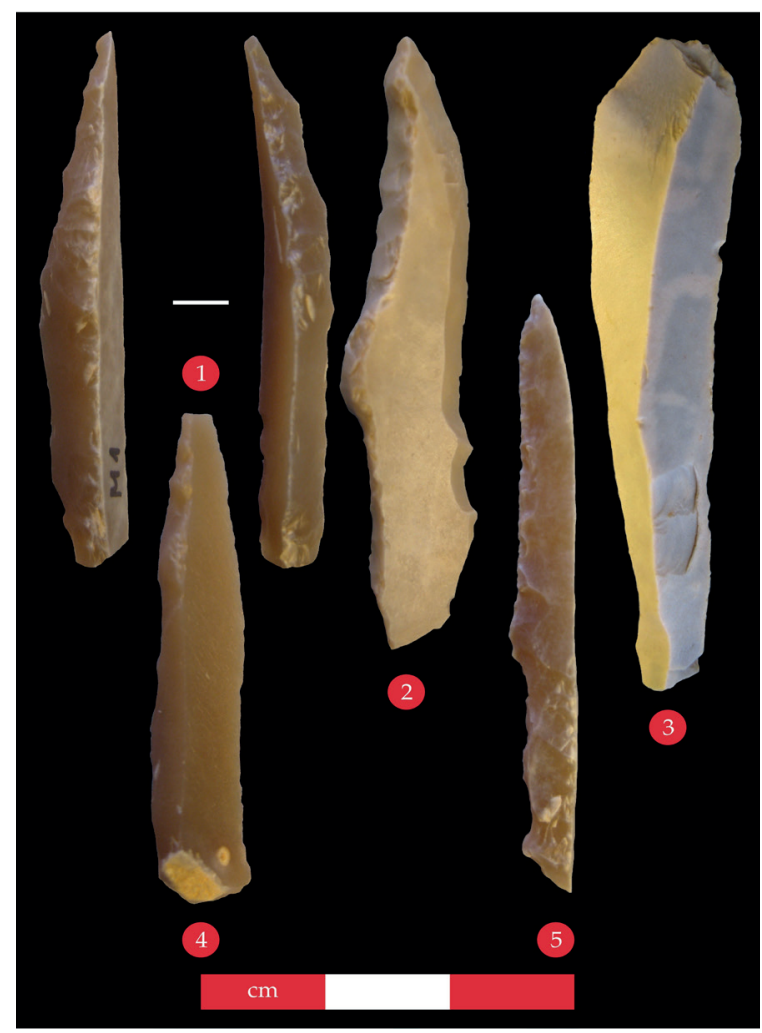

Fig. 21. Selected Mesolithic artefacts from site M1 near El Mekta. 1-2, 4-5 - microblades, 3 - unretouched microblade.

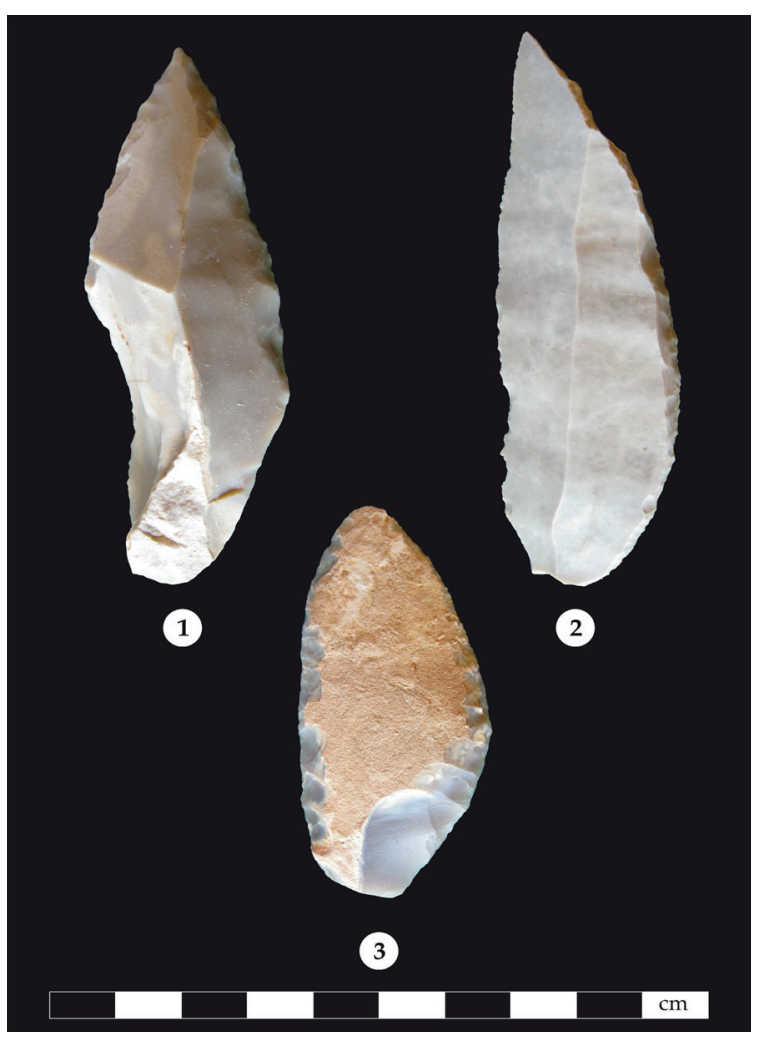

Fig. 20. Selected Mesolithic artefacts from site M1 near El Mekta. 1-2 - backed blades, 3 - side-scraper.

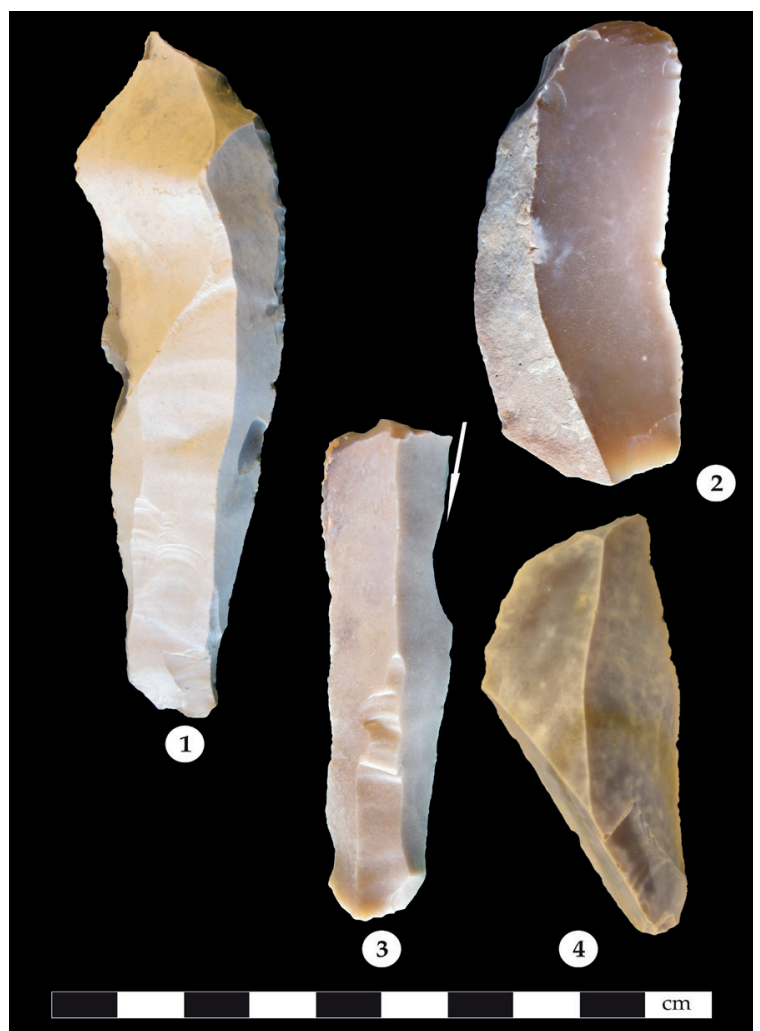

Fig. 22. Selected Mesolithic artefacts from site M2 near El Mekta. 1 - retouched blade, 2 - end-scraper, 3 - burin, 4 - partially backed blade. 


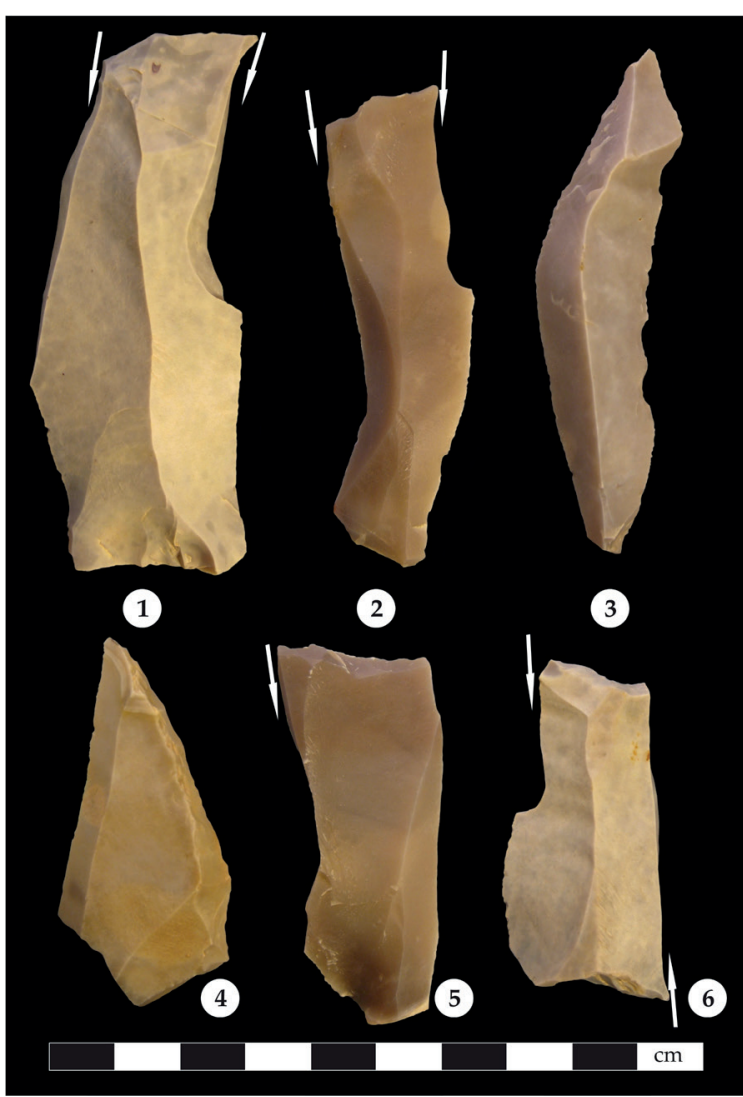

Fig. 23. Selected Mesolithic artefacts from site M2 near El Mekta. 1-2, 5-6 - burins, 3 - retouched blade, 4 - backed blade.

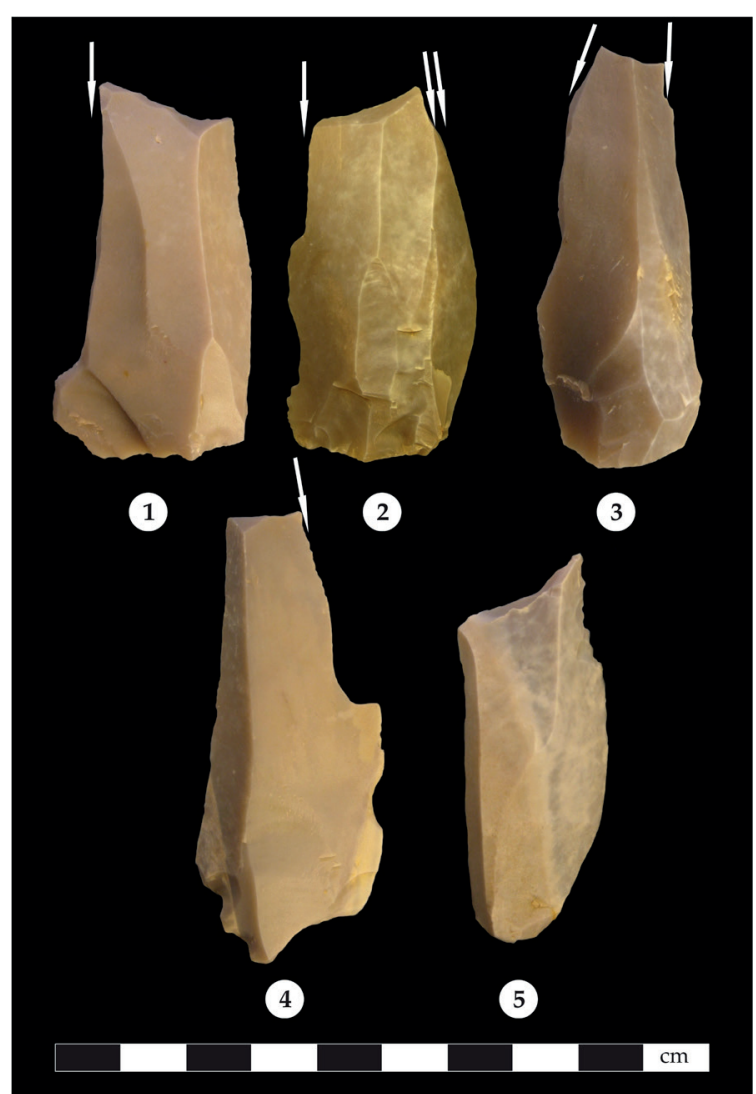

Fig. 24. Selected Mesolithic artefacts from site M2 near El Mekta. 1-4 - burins, 5 - borer.

According to Balout, ${ }^{31}$ the backed blades make up a quarter to a third of the Typical Capsian toolkits and were sometimes made by retouching burin offcuts. Balout refers to these artefacts as "aiguillons droit" a broader sense Gobert. ${ }^{32}$ Type 53 of the type list of Tixier ("Aiguillon droit") 33 is defined as an acute microblade, blunted rectilinear (more rarely concave) by retouches on an anvil, with a triangular cross-section, without an arris on one or the other surface, with a convex edge sometimes partially retouched, no longer showing the trace of the butt. This piece is obtained in a notable proportion from a primary burin spall. ${ }^{34}$ At the site of $M 1$, there are many exemplars of these types of artefacts (Fig. 21,1,4,5). The other Typical Capsian site M2 yielded a smaller lithic assemblage.

One interesting piece is a single end-scraper is made on a déjeté (obliquely angled) blade. Its arched, leftish working edge is asymmetrical, several times renewed (Fig. 22,2). There are two entirely intact exemplars of Type 36 of the type list of Tixier ("Lame à tète arquée"), ${ }^{35}$ a blade whose one end has an edge partially blunted by abrupt convex retouching. The distal end of the long, slender artefact $(111 \times 31 \times 13 \mathrm{~mm})$ in Fig. 22,1 is slightly pointed. The other tool is chunkier $(64 \times 28 \times 14 \mathrm{~mm})$ in Fig. 22,4. It can be assumed that these tools might have had the same or similar scraping function. There is a single specimen of "Couteaux à dos capsiens" (Type 37 of the type list of Tixier, "Lame à bord abattu arqué"). ${ }^{36}$

BALOUT 1981, 577.

GoBerT 1950.

TIXIER 1963, 87.

TIXIER 1963, 100, Fig. 35,10.

TIXIER 1963, 87.

TIXIER 1963, 87. 
The base of this blunted blade was broken long ago in a V-form, as the breakage surfaces have the same patination as the surface of the tool (Fig. 23,4). There is a rather atypical tool in Fig. 23,3. The blank of the tool is a rightish blade $(77 \times 17 \times 8.5 \mathrm{~mm})$. The distal part of the left side edge is finely retouched in a length of $37 \mathrm{~mm}$, on the concave right-side there are two retouched notches and use-retouch as well. The presence of the perforator (borer) (Fig. 24,5) should be considered as accidental.

\section{Discussion}

The Middle Palaeolithic

\section{Mousterian}

Levallois-Mousterian industries, with a predominant Levallois technique and a high presence of small bifaces, endscrapers, backed knives, side-scrapers, burins, points, and denticulates, are attested throughout the Maghreb (also known as Northwest Africa or Northern Africa) and the Sahara. The Mousterian, more common in North Africa than assumed some decades ago, has been dated to 160,000 BP in the Western Desert (Egypt), and between 121,000 and 87,000 BP in the Djebel lrhoud (Morocco), where the carrier of this industry was an archaic Homo sapiens without any relationship to the Neanderthals or to any oriental Homo erectus. ${ }^{37}$ North ward from the Brézina oasis (southern Saharan Atlas, Algeria), the Denticulate Mousterian was found in an alluvial terrace situated between 110,000 and 60,000 BP. ${ }^{38}$ A local technological evolution from Acheulean techniques has been envisaged for some sites. At Akka, in southern Morocco, a transitional final Acheulean/early Mousterian industry has been recovered in an altered palaeosol and fine-grained alluvial sediments. The assemblage is reported to be "typical Mousterian of Levallois facies" but includes a few Acheulean-type cleavers ${ }^{39}$ possibly inherited from Saharan Acheulean and could represent a final Acheulean stage transitional to the Mousterian..$^{40}$

An Acheulean-Mousterian continuum has also been evoked for the area of Touggourt (the site KM50) in Algeria. ${ }^{41}$ Some gigantic artefacts, particularly a series of blades, are sometimes found on Saharan sites characterised by Levallois debitage, mostly in the Ahaggar (southern Algeria, central Sahara) ${ }^{42}$ and in the Messak plateau (south-western Libya, central Sahara). ${ }^{43}$

They testify the presence of a particular and little-known type of industry that might well belong to a Mousterian of Acheulean Tradition.

\section{Aterian}

The Aterian is named after the type site of Bir el-Ater (Wadi Djebbana), south of Tébessa (Algeria). It is a Middle Stone Age (or Middle Palaeolithic) stone tool industry, which some authors consider a facies of the Mousterian with Levallois technology, often with blades. ${ }^{44}$ It is attested exclusively in North Africa and everywhere north of $18^{\circ}$ North from the Atlantic to the Western Desert in Egypt, during Marine Isotope Stage 4. The earliest Aterian dates to c. 145,000 years ago, at the site of Ifri

Smith et al. 2007.

Aumassip 2001, 48-49.

RoDrigue 1987, 489-496, Fig. 4,1, Fig. 5,2, Fig. 6.

RODRIGUE 2000, 29.

Aumassip 2001, 50.

Aumassip 2001, 51, Fig. 12.

CANCELlieRI - Di LERNIA 2013, 146.

TIXIER 1967. 
n'Ammar in Morocco. ${ }^{45}$ However, most of the early dates cluster around the beginning of the Last Interglacial, around 130,000 years ago, when the environment of North Africa began to ameliorate. It seems that Homo sapiens are responsible for the Aterian culture in the Maghreb. ${ }^{46}$ The Aterian disappeared around 40,000 BC in Tripolitania (northwestern part of Libya), 22,000 BC in the Maghreb, and probably 20,000 BC in the southern Sahara.

The Aterian is primarily distinguished through the presence of tanged or pedunculated tools ${ }^{47}$ generally taken to indicate hafting. Tanged tools did not necessarily serve hunting purposes or other functions related to meat consumption, such as butchering or scraping. Aside from side-scrapers and end-scrapers, the tang could be placed onto the base of almost all types of tools, including, borers, denticulates, and burins. Bifacially-worked, leaf-shaped tools are also a common artefact type in Aterian assemblages, and so are Levallois flakes and cores. The Aterian is one of the oldest examples of regional technological diversification, evidencing significant differentiation from older stone tool industries in the area, frequently described as Mousterian. The technological character of the Aterian has been debated for a long time. ${ }^{48}$ The problems defining the industry have related primarily to the fact that several similarities have been observed between the Aterian and other North African stone tool industries of the same date. ${ }^{49}$ Levallois reduction is widespread across the whole of North Africa throughout the Middle Stone Age, and scrapers and denticulates are ubiquitous. Bifacial foliates moreover represent a huge taxonomic category, and the forms and dimensions of such foliates associated with tanged tools are extremely varied. ${ }^{50}$ Assemblages with tanged tools, "the Aterian", have a significant temporal and spatial range. However, the exact geographical distribution of this lithic industry is uncertain. Though technologically the Aterian has a strong Levallois tendency, there is some production of blades using Levallois and other reduction methods. ${ }^{51}$

Some authors consider the Aterian as the result of the adaptation of nomadic humans to a barren landscape..$^{52}$ As a result of recent excavations, detailed data are available for the Contrabandiers Cave in Morocco. ${ }^{53}$ Tanged pieces are found only in the upper archaeological layers, while they are lacking in the lower layers. The site Ifri n'Ammar in Morocco shows that the Mousterian can be present after an Aterian phase within a stratified sequence. ${ }^{54}$ In Tunisia, such sites as Aïn Métherchem, El Guettar, and Wadi Akarit have been identified as "Proto-typical Aterian" because of the presence of tanged tools. The recently excavated site of Wadi Akarit yielded an archaeological level attributed to the "ProtoAterian". The occupation soil is dated by thermoluminescence to $90 \mathrm{ka}$. In the Meknassy Basin, at Ain El Guettar, two archaeological levels have been identified. The upper level is Mousterian, and the lower level is Aterian, with no transition from the Aterian to the Mousterian level..$^{55}$

To summarize the relationship between the two cultures, Dibble et al. have found that they overlap in many ways, including typological and technological characteristics of the lithic assemblages and chronology. That is why the authors tentatively refer to the two entities together as the AteroMousterian. ${ }^{56}$

45 Richter et al. 2010; Richter et al. 2012.

46 FEREMBACH 2001.

47 SCERRI 2013.

48 SCERRI 2013.

49 DibBle et al. 2013.

50 SCERRI 2013.

51 HAWKins 2001; HAWKins - KLEINDIENST 2001.

52 Cremaschi - Trombino 2001, 45.

53 DibBle et al. 2012.

54 Richter et al. 2010.

55 Aouadi-Abdeljaouad - Belhouchet 2008; Aouadi-Abdeljaouad - Belhouchet 2012.

56 DibBle et al. 2012, 13. 
The Late Upper Palaeolithic and Mesolithic

\section{The Iberomaurusian}

The Iberomaurusian is a microlithic industry characterized by high $(\geq 40 \%)$ frequencies of backed bladelets. Partially backed, obtuse-ended forms (blunt-ended backed bladelets) s7 $^{57}$ often constitute a high percentage. Other forms include straight-backed bladelets, scalene bladelets, bladelets pointed with a microburin facet (La Mouillah points) and backed bladelets with very light backing (Ouchtata retouch). ${ }^{58}$ Retouch is generally obverse and is found preferentially on proximal ends. Burins and geometrics generally constitute less than 1 per cent of an assemblage, but when the latter is present, segments are predominant. Microburins are common in all assemblages, but one tool form that seems to be restricted to the Iberomaurusian is the splintered piece (pièce esquillée)..$^{59}$ End-scrapers made on flakes are always present and can form up to 9.5 per cent of an assemblage. Tools are made from a wide selection of raw materials including flint, limestone, sandstone, quartzite, and various igneous rocks. Cores are generally small, with single platforms. They are often made on only partially utilized flint pebbles. ${ }^{60}$ Pyramidal forms are very rare and fluted (cannelé) cores such as those found in Capsian assemblages are absent. ${ }^{61}$

The Iberomaurusian sites can be found near the coasts of Morocco, Algeria, and Tunisia. A single major site is also known in Libya, Haua Fteah, where the industry is locally known as the "Eastern Oranian' and dated to ca. 14,000-10,000 BP. ${ }^{62}$ The Iberomaurusian seems to have appeared around the time of the Last Glacial Maximum (LGM), somewhere between ca. 25,000 and 22,500 cal BP. It should have lasted until the early Holocene ca. 11,000 cal. BP. In the Maghreb, from c. 18,000 to 9,500 $\mathrm{BC}$, the so-called Mechta-Afalou, Mechta el-Arbi or Mechtoid types (from the eponymous sites in Algeria) produced the lberomaurusian industries, mostly in coastal areas ranging from Tunis to eastern Morocco. However, lberomaurusian settlements are also known quite far inland, up to 2,000 $\mathrm{m}$ above sea level in the Atlas Mountains. They possessed an elaborate toolkit, including diversified thin tools: plenty of backed bladelets (up to 98 per cent of the equipment) but also borers, drills, burins, and microburins. ${ }^{63}$

At Grotte des Pigeons (Taforalt Cave, Morocco), the lberomaurusian follows the Aterian after a considerable hiatus. A series of conventional ${ }^{14} \mathrm{C}$ dates were obtained for Iberomaurusians layers. ${ }^{64}$

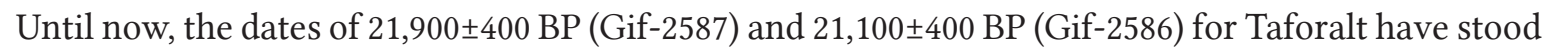
as the oldest for Morocco and are broadly comparable to the lowermost Iberomaurusian layer at Tamar Hat, Algeria which produced an age of $20,600 \pm 500$ BP (MC-822). ${ }^{65}$ Due to the post-Aterian hiatus, it was difficult to support the hypothesis of indigenous origins of the Iberomaurusian. Now some very old dates are known in Algeria (24,000 BC at Chetaïbi) and dozens of newly discovered sites, particularly at Aïn Khiar, have yielded microlithic industries, including pieces produced with the Levallois technique, that suggest a progressive facies. Thus, the Iberomaurusian culture could well be the outcome of a local evolution of the Aterian after the northern withdrawal of its bearers under the pressure of the aridity during Marine Isotope Stage $2 .{ }^{66}$

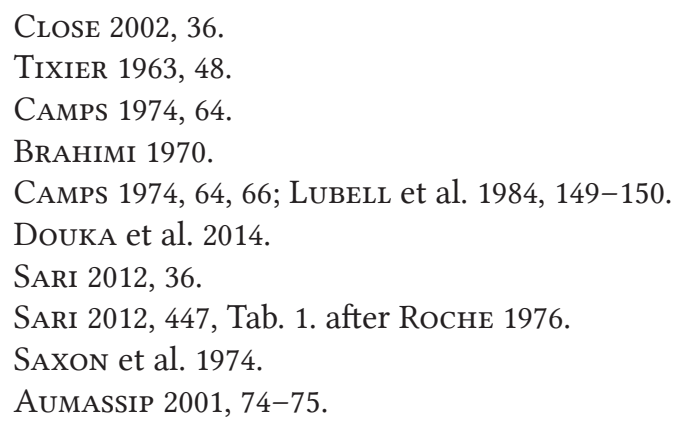


The Capsian

The Capsian culture appears around 9,500 BC, and the relative chronological position of its two main facies (Typical Capsian and Upper Capsian) has been the subject of considerable speculation. ${ }^{67}$ In the 1960s, these two complexes were considered as strictly consecutive phases, but in the 1970s it was argued that their labels should not conceal the fact that they are largely contemporaneous.

The Typical Capsian is defined essentially by the presence of large numbers of abruptly backed tools made on macrolithic flakes and blades, as well as by high frequencies of burins made on truncation. ${ }^{68}$ Characteristic tool forms include backed blades and endscrapers on blades or large flakes. Backed bladelets are always abundant $( \pm 20 \%)$, while geometrics are less important $(\leq 10 \%)$. When present, geometrics are generally dominated by segments and short triangles and are not as well made as those in the late stages of the Upper Capsian. Microburins are always present.

The Upper Capsian is characterized by abundant and varied geometric microliths (scalene triangles and trapezes) and other tools made on light bladelets that contrast with the heavier forms of the Typical Capsian. In the Typical Capsian zone (the Tébessa-Gafsa region), large tools do appear in Upper Capsian assemblages as well. The controlling factor seems to be the presence of abundant sources of large flint nodules. The distinction between Typical Capsian and Upper Capsian has become increasingly blurred as Typical Capsian assemblages with few burins and Upper Capsian assemblages with abundant burins have been identified. Both the Typical Capsian and the Upper Capsian abound in notched pieces.

The territory of the Upper Capsian (from the Tiaret area, $50 \mathrm{~km}$ east of the eponymous site of Gafsa in Tunisia) is more extensive than the area covered by the Typical Capsian, which is spread over a semicircle less than $200 \mathrm{~km}$ in radius south of Tébessa on both sides of the Algero-Tunisian border. The Capsian expansion to the south is poorly defined, and Camps globally labelled several Epipalaeolithic inventories as Ouarglian or Mellalian (after the eponymous site Sebhka Mellala in Algeria). ${ }^{69}$ Noura Rahmani showed that the geographical distribution of the Typical Capsian is strongly related to the availability of a very high-quality Upper Cretaceous Senonian flint frequent in the Tébessa-Gafsa region. This raw material was abundant enough to allow them to produce blades and bladelets "by technological strategies that resulted in a high wastage of flint". ${ }^{70}$ Conversely, in Upper Capsian industries, bladelet production by the pressure-flaking technique allowed serial production, high productivity, and standardisation of microliths. Although there is about a five-hundred-year period of the contemporaneity of the Typical Capsian and Upper Capsian (between 8,000 and 7,500 B.P.), the adoption of pressure-flaking around 8,200 cal B.P. by the latter group defines a major technological change from the Typical Capsian. ${ }^{71}$

When trying to elucidate the origins of this important culture, authors have particularly highlighted its Mediterranean, African and Oriental affinities: three components still operating at present throughout the Maghreb and the Sahara. Camps supported the hypothesis of an Eastern origin, ${ }^{72}$ but the reanalysis of Noura Rahmani's data bestows a new vigour on the model of Peter Sheppard and David Lubell, ${ }^{73}$ suggesting some local evolution from the Iberomaurusian. In short, not only is there "no evidence supporting the development or derivation of the Capsian lithic industry from

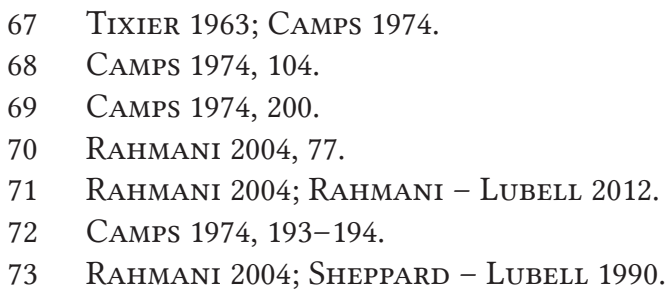


outside the Maghreb", but "a very strong argumentation can be made for continuity in lithic traditions from the Iberomaurusian through to the early Capsian and west Algerian assemblages." ${ }^{.4}$

Sheppard notes 75 that Types 48 and 49 ("Pointe de Mechta El-Arbi" and "Pointe du Chacal") have a quite distinctive base treatment which may have been of stylistic significance. Tixier notes ${ }^{76}$ that the "Pointe du Chacal" is associated with a very well developed or late Upper Capsian, and associates the "Pointe de Mechta El-Arbi" with much older assemblages. However, Chacal points seem to appear already in the later phase of Iberomaurusian. At the rock shelter of Afalou Bou Rhummel

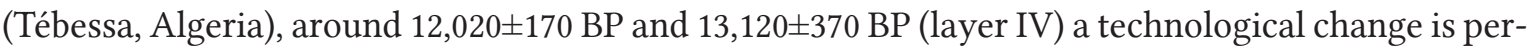
ceived. There is a decrease in the number of backed bladelets for the development of sophisticated weapons such as Ain Keda and Chacal points with many triangles and rare trapezoids. ${ }^{77}$

\section{Summary}

The present study is only a brief presentation of the artefacts collected from the surface in the area of Gafsa, Tunisia. It is by no means exhaustive, since, as is clear from the sketchy chronological and cultural classification of the finds, the period covered is at least 100,000 years of human prehistory in North Africa. However, the value of the collection and its future complete scientific processing lies precisely in this fact, as it will provide a more comprehensive picture of the prehistory of a narrower area, which will hopefully contribute greatly to a better understanding of the formation and chronological relations of these cultural units.

\section{References}

Aouadi-Abdeljaouad, N. - Belhouchet, L. 2008: Recent prehistoric field research in Central Tunisia: prehistoric occupations in the Meknassy Basin. African Archaeological Review 25:1-2, 75-85. DOI: 10.1007/ s10437-008-9027-z

Aouadi-Abdeljaouad, N. - Belhouchet, L. 2012: Middle Stone Age in Tunisia: present status of knowledge and recent advances. In: Hublin, J.-J. - McPherron, S. P. (eds): Modern Origins: A North African Perspective. New York, 143-155. DoI: 10.1007/978-94-007-2929-2_10

Aumassip, G. 2001: L'Algérie des premiers hommes. Éditions de la Maison des sciences de l'homme. Paris. DoI: 10.4000/books.editionsmsh.6563

BAlout, L. 1981: The prehistory of North Africa. In: Ki-Zerbo, J. (ed.): General History of Africa Volume I. Methodology and African Prehistory. Berkeley - London, 568-584.

Belhouchet, L. - Mulazzani, S. - Pelegrin, J. 2014: Evolution of a $9^{\text {th }}-8^{\text {th }}$ mill. cal BP Upper Capsian site 2014. The techno-typological study of bladelet production at SHM-1 (Hergla, Tunisia), Quaternary International 320, 28-42. DOI: 10.1016/j.quaint.2013.05.006

BoRDEs, F. 1947: Étude comparative des différentes techniques de taiile du silex et des roches dures. L'Anthropologie 51, 1-29.

Brahimi, C. 1970: L'Iberomaurusien littoral de la region d'Alger. Mémoire du Centre de Recherches Anthropologiques, Préhistoriques et Ethnographiques 13. Paris.

CAmps, G. 1974. Les civilisations préhistoriques de l'Afrique du Nord et du Sahara. Paris, 366.

SHEPPARD - LUBELL 1990, 66. SHEPPARD 2016, 66.

TIXIER 1963, 99.

SARI 2012, 66, 2014, 132 after HACHI 2003, 230. 
Cancellieri, E. - Di Lernia, S. 2013: Middle Stone Age human occupations and dispersals in the Messak plateau (SW Lybia, central Sahara). Quaternary International 300, 142-152. DoI: 10.1016/j.quaint.2012.08.2054

Close, A. E. 2002: Backed Bladelets Are a Foreign Country. In: Elston, R. G. - Kuhn, S. L. (eds): Thinking Small: Global Perspectives on Microlithization. Archaeological Papers of the American Anthropological Association 12. Arlington, 31-44.

Cremaschi, M. - Trombino, L. 2001: The formation processes of the stratigraphic sequence of the site and their palaeoenvironmental implications. In: Garcea, E. A. A. (ed.): Uan Tabu in the Settlement History of the Libyan Sahara. Florence, 15-23.

Dibble, H. L. -Aldeias, V. - Alvarez-Fernández, E. - Blackwell, B. - Hallett-Desguez, E. - Jacobs, Z. Goldberg, P. - Morala, A. - Meyer, M. C. - Olszewski, D. I. - Reed, K. - Reed, D. - Richter, D. Roberts, R. G. - Sandgathe, D. - Schurmans, U. - Skinner, A. - El-Hajraoui, M. 2012: New excavations at the site of Contrabandiers Cave, Morocco. Paleoanthropology 145-201. DoI: 10.4207/PA.2012.ART74

Dibble, H. L. - Aldeias, V. - Jacobs, Z. - Olszewski, D. I. - Rezek, Z. - Lin, S. C. - Alvarez-Fernández, E. - Barshay-Szmidt, C. C. - Hallett-Desguez, E. - Reed, D. - Reed, K. - Richter, D. - Steele, T. E. - Skinner, A. - Blackwell, B. - Doronicheva, E. - El-Hajraoui, M. 2013: On the industrial attributions of the Aterian and Mousterian of the Maghreb. Fournal of Human Evolution 64, 194-210. Dor: 10.1016/j.jhevol.2012.10.010

Douka, K. - Jacobs, Z. - Lane, C. - Grün, R. - Farr, L. - Hunt, C. - Inglis, R. H. - Reynolds, T. - Albert, P. Aubert, M. - Cullen, V. - Hill, E. - Kinsley, L. - Roberts, R. G. - Tomlinson, E. - Wulf, S. BARKER, G. 2014: The chronostratigraphy of the Haua Fteah cave (Cyrenaica, northeast Libya). fournal of Human Evolution 66, 39-63. DoI: 10.1016/j.jhevol.2013.10.001

FerEmbach, D. 2001: Evolution du peuplement du maghreb des origines au Néolithique. In: CNRPH. (ed.): L'homme Maghrébin et son environnement depuis 100000 ans. Alger, 123-129.

GoBert, E.-G. 1950: El-Mekta, station princeps du Capsien. Karthago, 29-30.

HAcHI, S. 2003: Les cultures de l'Homme de Mechta-Afalou: le gisement d'Afalou Bou Rhummel (massif des Babors, Algérie): les niveaux supérieurs 13.000-11.000 BP. Alger.

Hawkins, A. L. 2001: Getting a handle on Tangs: Defining the Dakhleh Unit of Aterian Technocomplex - a Study in Surface Archeology from the Western Desert of Egypt. PhD dissertation, University of Toronto.

Hawkins, A. L. - KLeindienst, M. T. 2001: The Aterian. In: Peregrine, P. N. et al. (eds): Encyclopedia of Prehistory. Volume 1: Africa. 23-45. DoI: 10.1007/978-1-4615-1193-9_2

Le Quellec, J.-L. 2014: Prehistory in North Africa after the Middle Palaeolithic. In: Renfrew, C. - Bahn, P. G. (eds): The Cambridge World Prehistory. Cambridge, 151-164. DoI: 10.1017/CHO9781139017831.012

Lubell, D. - Sheppard, P. - Jackes, M. 1984: Continuity in the Epipalaeolithic of Northern Africa with emphasis on the Maghreb. In: Wendorf, F. - Close, A. (eds): Advances in World Archaeology. Vol. 3. Orlando, 143-191.

MoRel, J. 1974: La station éponyme de l'Oued Djebbana à Bir el Ater (Est algérien). Contribution à la connaissance de son industrie et de sa faune. L'Anthropologie 78, 53-80.

MOREL, J. 1978: L'industrie atérienne de l'Oued Djouf el Djemel. Comparison avec l'industrie de l'Oued Djebbana. Le complexe atérien au Maghreb Oriental. Bull. de la Société Préhistorique Française 75, 487-500. DoI: $10.3406 /$ bspf.1978.8530

NeHRen, R. 1992: Zur Prähistorie der Maghrebländer (Marokko-Algerien-Tunesien). Materialen zur Allgemeinen und Vergleichenden Archaologie 49. Mainz am Rhein.

RAHMANi, N. 2004: Nouvelle interprétation de la chronologie capsienne (Épipaléolithique du Maghreb). Bulletin de la Société préhistorique française 101:2, 345-360. DOI: 10.3406/bspf.2004.12996

Rahmani, N. - LubelL, D. 2012: Early Holocene climate change and the adoption of pressure technique in the Maghreb: The Capsian sequence at Kef Zoura D (Eastern Algeria) (Chapter 4). In: Desrosiers, P. M. 
(ed.): The Emergence of Pressure Blade Making. From Origin to Modern Experimentation. Boston, 465-496. DOI: 10.1007/978-1-4614-2003-3

Richter, D. - Moser, J. - NAmi, M. - Eiwanger, J. - Mikdad, A. 2010: New chronometric data from Ifri n'Ammar (Morocco) and the chronostratigraphy of the Middle Palaeolithic in the Western Maghreb. fournal of Human Evolution 59:6, 672-679. DOI: 10.1016/j.jhevol.2010.07.024

Richter, D. - Moser, J. - NAmi, M. 2012: New data from the site of Ifri n'Ammar (Morocco) and some remarks on the chronometric status of the Middle Paleolithic in the Maghreb. In: Hublin J.-J. - McPherron, S. P. (eds): Modern Origins: A North African Perspective. New York, 61-78. DOI: 10.1007/978-94-007-2929-2

Rodrigue, A. 1987: Nouveaux éléments sur le Moustérien du Maroc - La station d'Akka (Maroc Saharien). L'Anthropologie 91:2, 483-496.

Rodrigue, A. 2000: Préhistoire du Maroc. Casablanca: La Croisée des Chemins, 119 p.

SARI, L. 2012: L'Ibéromaurusien. Culture du Paléolithique supérieur tardif. Apoporoche technologique des productions lithiques taillées de Tamar Hat, Rassel et Columnata (Algérie). Thése de Doctorat, Université de Paris X-Nanterre.

SARI, L. 2014: Technological change in Iberomaurusian culture: The case of Tamar Hat, Rassel and Columnata lithic assemblages (Algeria). Quaternary International 32, 131-142. DOI: 10.1016/j.quaint.2013.04.014

Saxon, E. C. - Close A. - Cluzel, C. - Morse, V. - Shackleton, N. J. 1974: Results of recent excavations at Tamar Hat, Libyca 22, 49-91.

Scerri, E. M. L. 2013: The Aterian and its place in the North African Middle Stone Age. Quaternary International 300, 111-130. DOI: 10.1016/j.quaint.2012.09.008

Sheppard, P. 2016: The Lithic Assemblage. In: Lubell, D. (ed.) Holocene prehistory in the Télidjène basin, Eastern Algeria: Capsian occupations at Kef Zoura D and Aïn Misteheyia. Oxford, 41-85. DoI: 10.2307/j.ctvxrq0p7.5

Sheppard, P. - Lubell, D. 1990: Early Holocene Maghreb prehistory: an evolutionary approach. Sahara 3, 63-70.

Smith, T. M. - Tafforeau, P. - Reid, D. J. - Grün, R. - Eggins, S. - Boutajiout, M. - Hublin, J.-J. 2007: Earliest evidence of modern human life history in North African early Homo sapiens 104, 6128-6133. DOI: $10.1073 /$ pnas.0700747104

Tixien, J. 1963: Typologie de l'Epipaleolithique du Maghreb. Mémoires du centre de recherches anthropologiques, préhistoriques et ethonographiques 2. Paris.

Tixier, J. 1967: Pièces pédonculées Atériennes du Maghreb et du Sahara: Types 1-30. Fiches typologiques africaines 3. Paris. 